\title{
INITIAL PERFORMANCE EVALUATION OF MAJOR COMPONENTS IN THE HEAD-END REPROCESSING SOLIDS HANDLING SYSTEM
}

by

E. J. COOK and P. C. RICHARDS

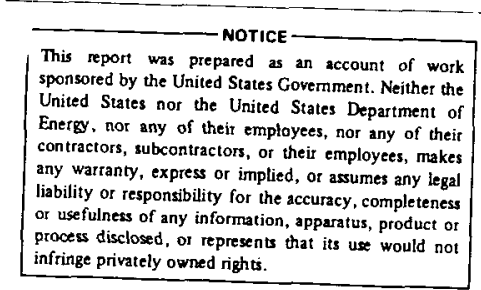

Prepared under Contract EY-76-C-03-0167 Project Agreement No. 53 for the San Francisco Operations Office U.S. Energy Research and Development Administration This document is

\begin{tabular}{l} 
PUBLICLY RELEASABLE \\
Bam Steal \\
\hline Authorizing Official \\
Date: 1.10 .0 ?
\end{tabular}

GENERAL ATOMIC PROJECT 3225 DATE PUBLISHED: SEPTEMBER 1977

\section{GENERAL ATOMIC COMPANY}




\section{DISCLAIMER}

This report was prepared as an account of work sponsored by an agency of the United States Government. Neither the United States Government nor any agency Thereof, nor any of their employees, makes any warranty, express or implied, or assumes any legal liability or responsibility for the accuracy, completeness, or usefulness of any information, apparatus, product, or process disclosed, or represents that its use would not infringe privately owned rights. Reference herein to any specific commercial product, process, or service by trade name, trademark, manufacturer, or otherwise does not necessarily constitute or imply its endorsement, recommendation, or favoring by the United States Government or any agency thereof. The views and opinions of authors expressed herein do not necessarily state or reflect those of the United States Government or any agency thereof. 


\section{DISCLAIMER}

Portions of this document may be illegible in electronic image products. Images are produced from the best available original document. 
The General Atomic cold head-end reprocessing pilot plant has been built to demonstrate the feasibility of the proposed commercial reprocessing flowsheet, in particular its integrated operation. This integration is accomplished in part by the solids handling system, which is designed to provide transfer of material at required rates between different steps in the process and to provide the required surge capacity. The major components of the solids handling system have been tested in order to verify or upgrade the design. The components described here are: inlet filters, conveying lines, bunkers, in-bunker filters, blowers, level sensors, feeders, and weigh cells. By and large, the equipment has performed as expected. Feeding of the various materials in the system has received considerable attention, and several improvements were necessary. The system is now equipped to perform its function of serving the needs of the other unit operations in the pilot plant. 
CONTENTS

ABSTRACT . . . . . . . . . . . . . . . . . . . iii

1. INTRODUCTION . . . . . . . . . . . . . . . . . . 1

2. HEAD-END REPROCESSING FLOWSHEET . . . . . . . . . . . . 7

3. SOLIDS HANDLING SYSTEM DESIGN . . . . . . . . . 10

3.1. Design Description and Qualification.......... 10

3.2. Design Criteria . . . . . . . . . . . . . 12

3.2.1. Inlet Filters . . . . . . . . . . . 12

3.2.2. Conveying Lines . . . . . . . . . . 12

3.2.3. Bunkers. . . . . . . . . . . . . . 12

3.2.4. In-Bunker Filters . . . . . . . . . . 13

3.2.5. Blowers ............... 13

3.2.6. Level Sensors . . . . . . . . . . . 13

3.2.7. Feeders ................. 13

3.2.8. Weigh Cells . . . . . . . . . . . 14

4. MAJOR COMPONENT TESTING . . . . . . . . . . . . 15

4.1. Inlet Filters. . . . . . . . . . . . . . 15

4.1.1. Description ............... 15

4.1.2. Testing ................ 15

4.1.3. Acceptability . . . . . . . . . . . 18

4.2. Conveying Lines . . . . . . . . . . . . . 18

4.2.1. Description ............... 18

4.2.2. Future Testing .............. 19

4.3. Bunkers. . . . . . . . . . . . . . 19

4.3.1. Description .............. 19

4.3.2. Testing . . . . . . . . . . . . 22

4.3.3. Acceptability . . . . . . . . . . . 26

4.4. In-Bunker Filters . . . . . . . . . . . . . . 27

4.4.1. Description ............... 27 
4.4.2. Testing ................. . 27

4.4.3. Acceptability ............... 33

4.5. Blowers . . . . . . . . . . . . . . 33

4.6. Level Sensors . . . . . . . . . . . . 36

4.6.1. Description . . . . . . . . . . . . 36

4.6.2. Testing and Acceptability . . . . . . . . . 36

4.7. Feeders . . . . . . . . . . . . . . . 39

4.7.1. Description . . . . . . . . . . . 39

4.7.2. Feeding Through Orifices - General Comments . . . 39

4.7.3. Testing . . . . . . . . . . . . . 43

4.7.4. Acceptability .............. 51

4.7.5. Improvements ............... . 51

4.8. Weigh Cells . . . . . . . . . . . . 52

4.8.1. Description . . . . . . . . . . . 52

4.8.2. Testing................. 59

4.8.3. Acceptability . . . . . . . . . . . 61

5. ACKNOWLEDGMENTS . . . . . . . . . . . . . . . . . . 63

REFERENCES ........................... . . 64

FIGURES

1. HTGR fuel element . . . . . . . . . . . . . . . . . 2

2. HTGR coated fuel particles . . . . . . . . . . . . . . 3

3. GA HTGR reprocessing cold pilot plant arrangement . . . . . . . 5

4. Cold head-end layout . . . . . . . . . . . . . . 8

5. Solids handling subsystems . . . . . . . . . . . . . 11

6. Conveying line inlet filter................ 16

7. End of a pneumatic conveying line . . . . . . . . . . . . 20

8. Aerated cone and bunker outlet . . . . . . . . . . . . . 21

9. Design and actual solids handling system bunker volumes . . . . . 24

10. Porous stainless steel in-bunker filter pipes . . . . . . . . 28

11. In-bunker filter blow-back assembly . . . . . . . . . . . 29

12. In-bunker filter pressure drop measurement arrangement and argon inlet line . . . . . . . . . . . . . . 30 
13. Rotary blower used to provide moving air for pneumatic

conveying . . . . . . . . . . . . . . . . . . 35

14. Blower performance specifications (Gardner-Denver 3PDR9) • • . 37

15. Ultrasonic level sensor [5.08 cm (2 in.) diameter] used

for indicating a maximum safe level in a storage bunker . . . . 38

16. Primary burner feeder . . . . . . . . . . . . . . . . 40

17. Particle classifier feeder . . . . . . . . . . . . . 41

18. Flow rate into primary burner versus star valve speed setting...................... . . 45

19. Variation of flow rate of simulated fresh feed with time . . . 46

20. Variable width knifegate in position under the primary burner ........................ 47

21. Particle classifier vibrating feeder calibration curves . . . 50

22. Rotary feeder valve test results $[0.05 \mathrm{~m}$ (2 in.) inlet] . . . 53

23. Rotary feeder valve test results $[0.010 \mathrm{~m}$ (4 in.) inlet $]$. . . 54

24. Rotary feeder installed under the primary burner product bunker ...................... 55

25. Bunker load cell used for monitoring the weight of material within................. 56

26. Bunker and support cage $[63.50 \mathrm{~cm}$ (25 in.) diameter bunker] . . . . . . . . . . . . . . . . 57

27. Bunker tie bar used to prevent rotation of the bunker on its load cells... . . . . . . . . . . . . . . . 58

\section{TABLES}

1. Measured pressure drop across inlet filters . • • • • • • . 17

2. Effective bunker volumes. • • • • • • • • • • • • . • . . 25

3. Size distribution of sample wipes . . . . . . . . . . . . . . 32

4. Filter loading tests . . . . . . . . . . . . . . . . 34

5. Particle classifier feeder capacities with BISO/TRISO fuel particles . . . . . . . . . . . . . . . . . . . . . . . 4 49

6. Bunker design basis weight capacities . . . . . . . . . . . . 60

7. Accuracies of weigh cell systems . . . . . . . . . . . . 62 


\section{INTRODUCTION}

High-temperature gas-cooled nuclear reactors (HTGRs) have as fuel sma11 coated particles which are embedded in fuel elements made from graphite, which acts as a neutron moderator (Fig. 1). The reactor utilizes thorium by converting it to U-233. Thorium can be incorporated into the fuel in a number of ways. In order to optimize the thorium-uranium fuel cycle, a system of separate fuel particles has evolved (Ref. 1). The two types of particles used are characterized by the coatings applied to them (Fig. 2). BISO particles are coated with a relatively porous buffer layer of carbon and then with a dense coating of pyrolytic carbon. TRISO coatings, in addition, have a silicon carbide coating placed between two layers of dense pyrolytic carbon. The SiC layer provides a means of separating these particles from the BISO particles in head-end reprocessing operations; it a1so enhances fission product retention in the fissile particles. BISO coatings are used for particles initially loaded only with thorium oxide, while TRISO coatings are used for particles loaded with uranium. After irradiation, the BISO fertile particles contain quantities of U-233. The separation of the fertile particles from the fissile TRISO particles and the subsequent recovery of the bred U-233 for use in refabricated fuel is an indispensable part of the recycle of HTGR fuel.

The development and demonstration of recycle technology is the goal of the Nationa1 HTGR Fue1 Recycle Program. The Program development activities are divided into a number of tasks (e.g., Task 200, Reprocessing Development) which in turn are divided into subtasks (e.g., Subtask 230, Dry Solids Handing). The work to be carried out follows a sequence of development stages: 


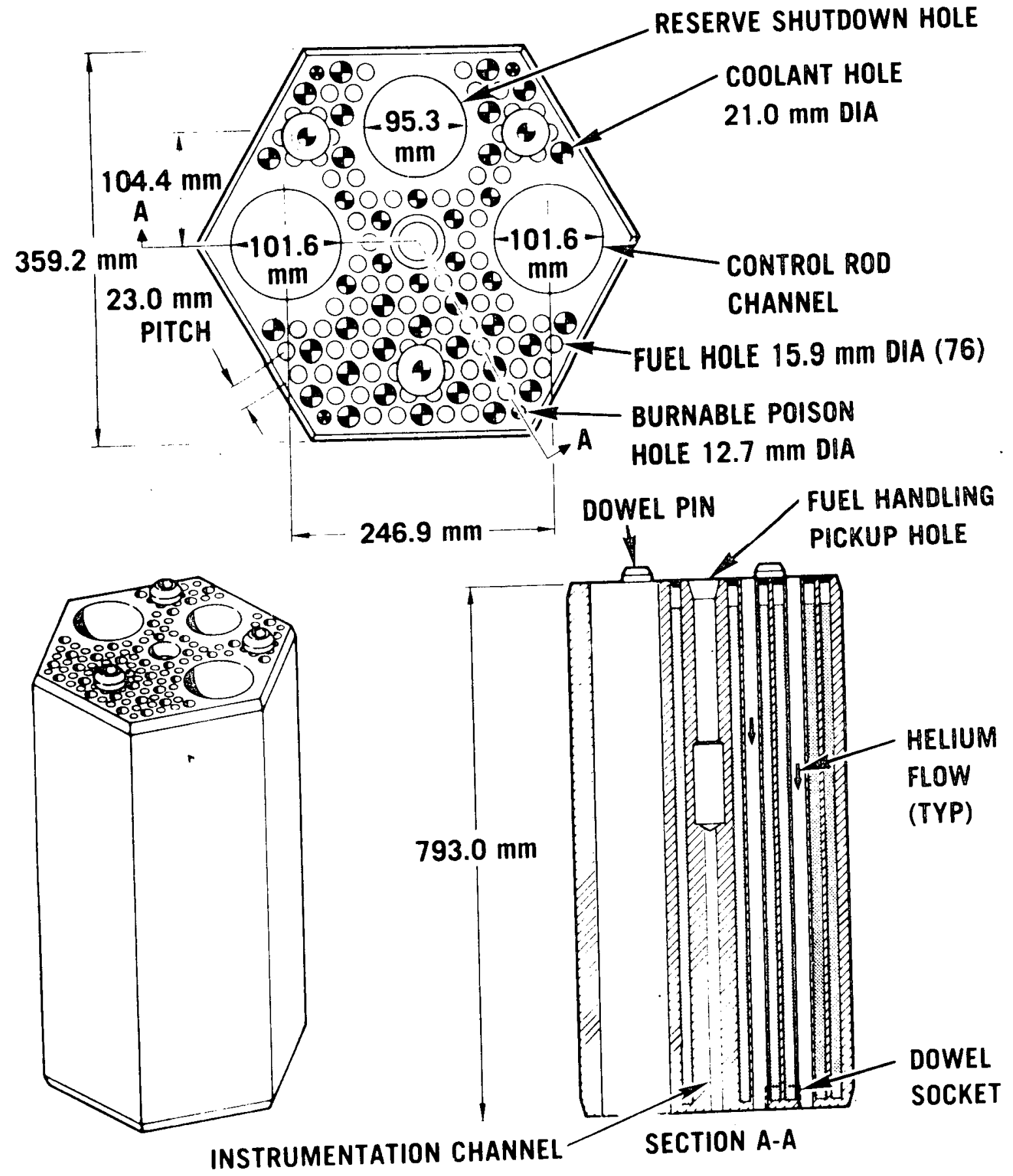

Fig. 1. HTGR fuel element 


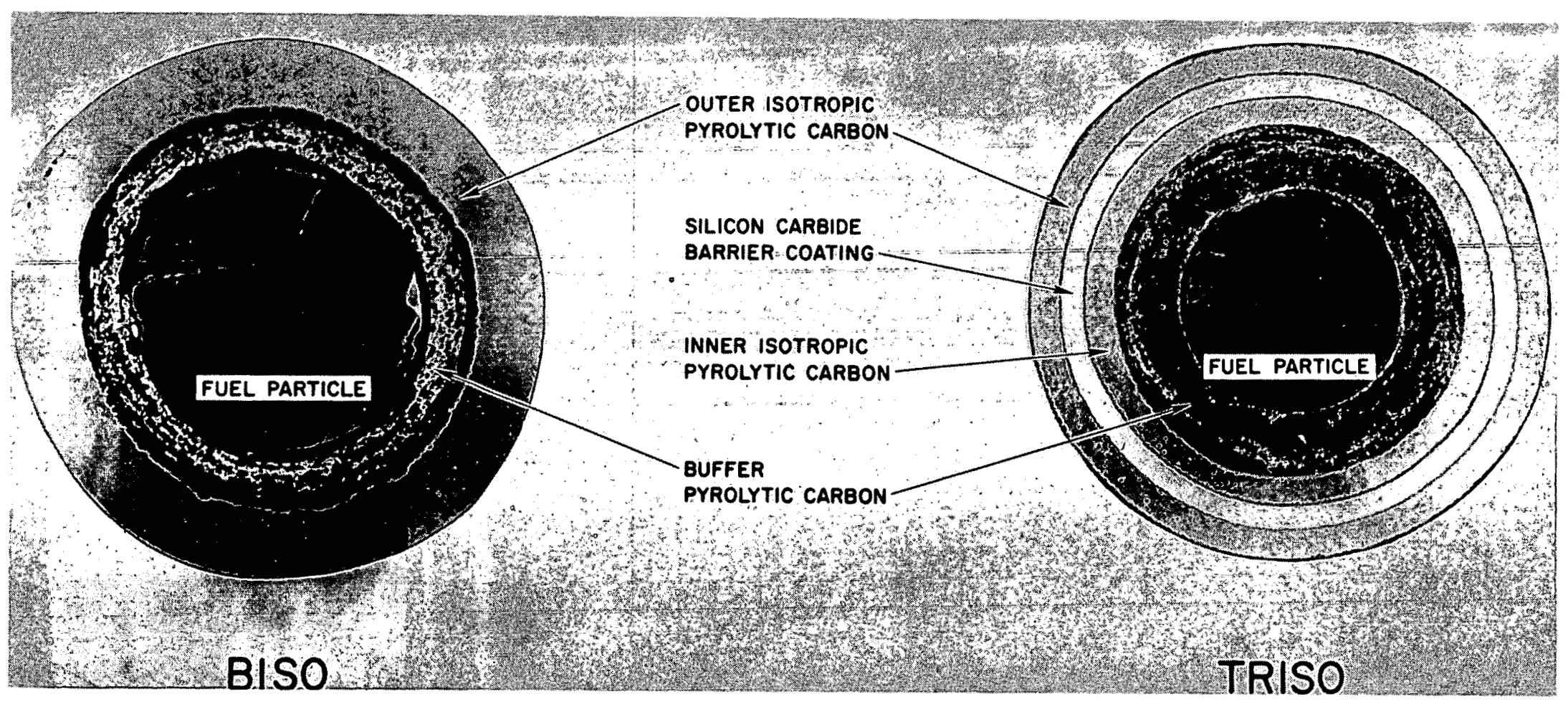

K22654

Fig. 2. HTGR coated fuel particles 
1. Cold laboratory development.

2. Hot laboratory development.

3. Cold engineering development.

4. Hot engineering development.

5. Cold prototype development.

6. Procedure development.

All stages of a11 subtasks must be completed for the demonstration of the HTGR fuel cycle in an HTGR Recycle Demonstration Facility (HRDF).

In June 1976, General Atomic completed the construction of a cold engineering scale head-end pilot plant (Fig. 3). The purpose of the plant is the demonstration of the feasibility of the technology on an acceptable scale. In the coming years it will evolve into a cold prototype. In the year since its completion, each system within the head-end pilot plant has been used for design verification experiments (or qualification testing). This report describes the results obtained with major components in the solids handling system. 


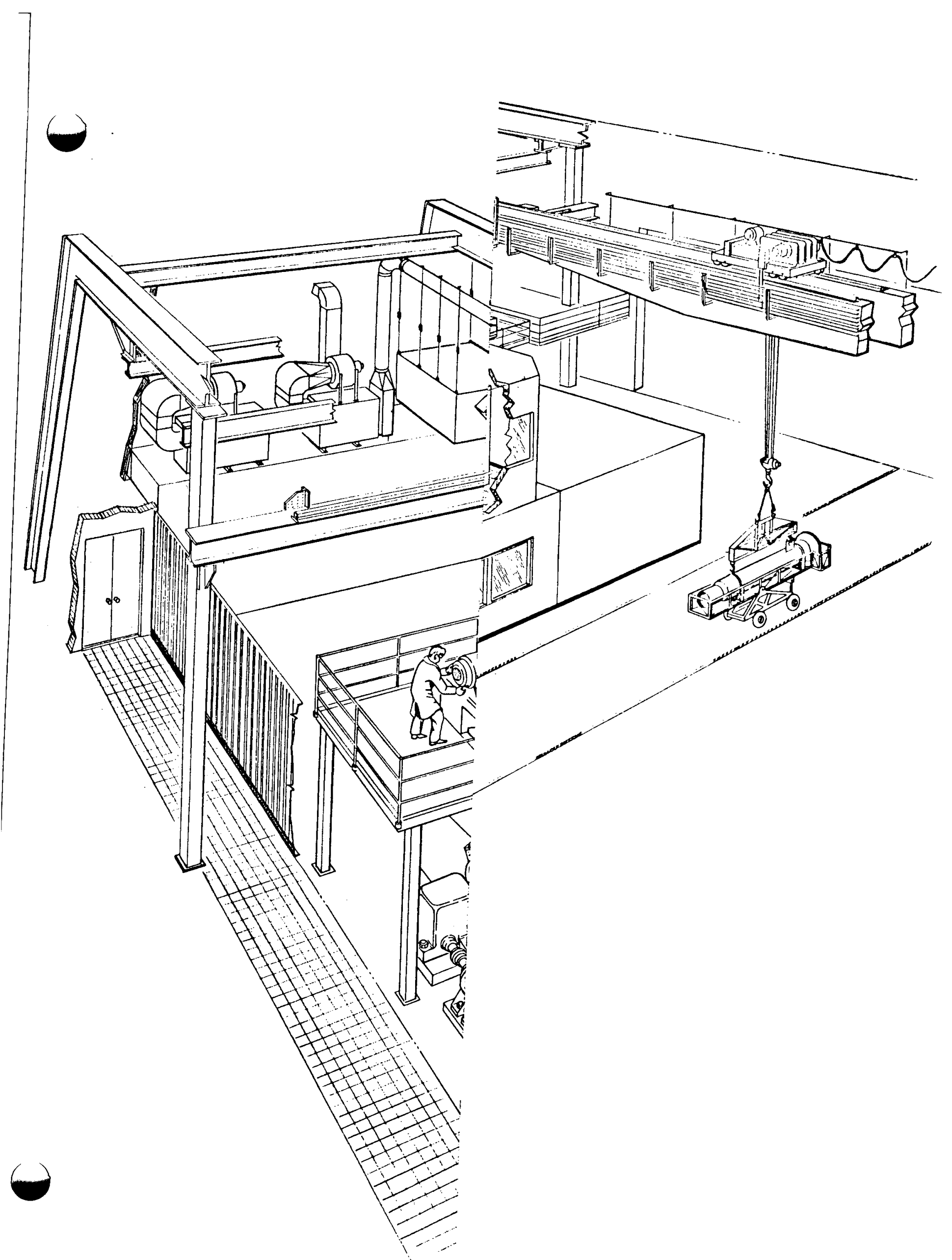

Fig. 3. GA HTGR reprocessing cold pilot plant arrangement 


\section{HEAD-END REPROCESSING FLOWSHEET}

The dry head-end of the reprocessing flowsheet must prepare fissile and fertile particles for dissolution and solvent extraction. It comprises fuel element size reduction, crushed fuel element burning, particle classification, particle crushing, and crushed particle burning (Ref. 1). Unit operations are connected by the solids handling system (Fig. 4).

Fuel elements are reduced to $-3 / 16$ in. $(4760 \mu \mathrm{m})$ in a series of crushers (two overhead eccentric jaw crushers and one double-roll crusher) which are mounted in one frame, designated Uniframe. After screening, the crushed material is conveyed pneumatically to a product bunker and then to the feed bunker of the fluidized-bed crushed fuel element burner (or primary burner). The graphite and outer carbon coatings of the fuel particles are burned off and the product is then conveyed to the primary burner product bunker. If the product is within specification, it is transferred to the pneumatic classifier feed bunker. If it contains excess carbon or graphite, it can be recycled to the primary burner feed bunker. The burnedback fuel particles are fed into a moving air stream within a zig-zag classification column.

The TRISO fissile particles are carried out of the top of the classifier, and the heavier BISO particles fall out the bottom ready for dissolution and solvent extraction. In the event of an unsatisfactory separation, particles from either or both of the classifier product bunkers can be recycled for reclassification.

The burned-back TRISO particles contain inner carbon coatings and combustible metal carbides which must be burned prior to dissolution. They are conveyed to a particle crusher where they are crushed. The 
FUEL ELEMENT SIZE REDUCTION SYSTEM
PRIMARY BURNER

PNEUMATIC CLASSIFICATION
SECONDARY BURNER
PARTICLE CRUSHER

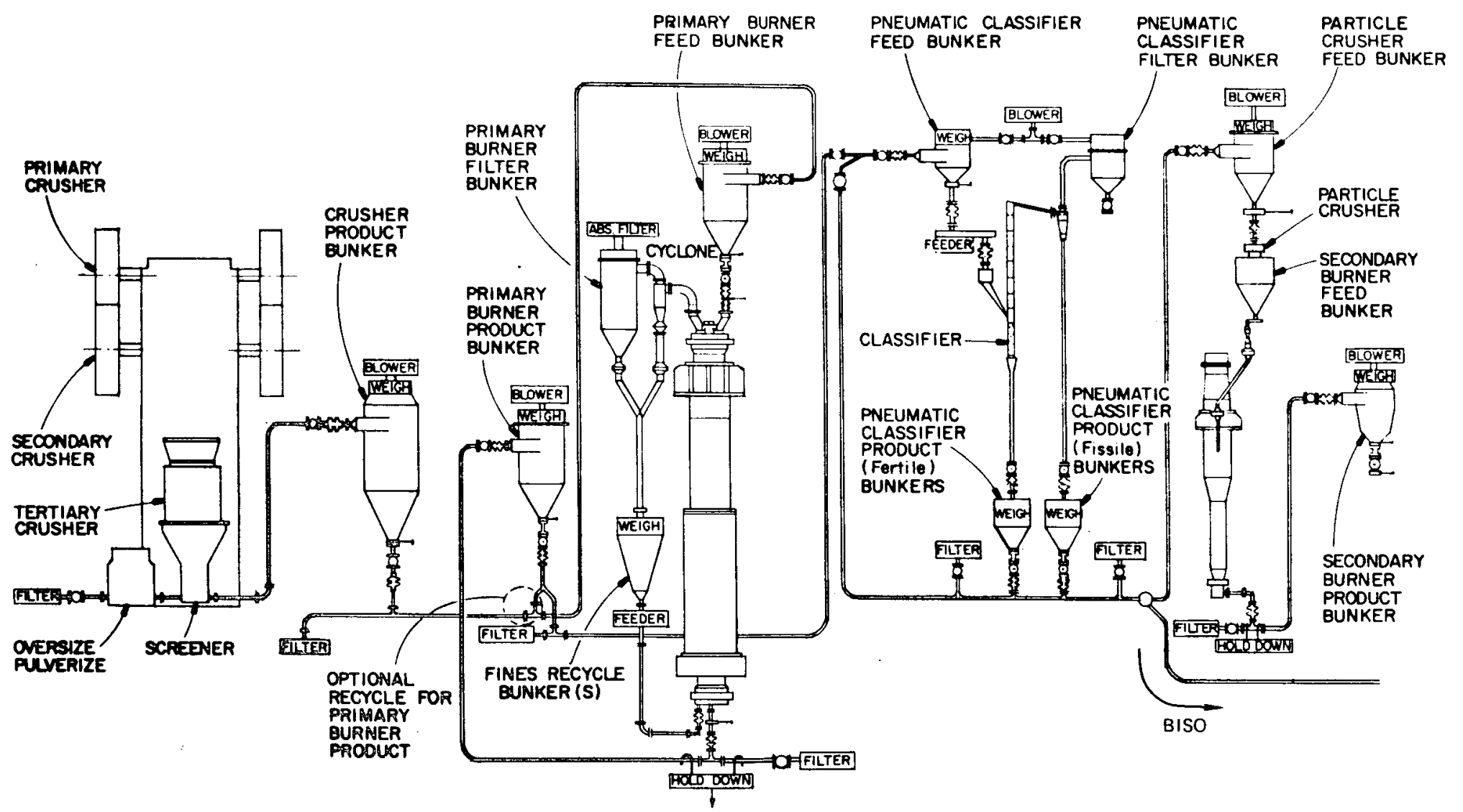

Fig. 4. Cold head-end layout 
crushed particles are then fed to the fluidized-bed crushed particle burner (or secondary burner), which combusts carbon and converts heavy metal carbides to oxides. Product from the secondary burner is transported pneumatically to the secondary burner product bunker.

The economics of fuel reprocessing require an optimal separation of fissile and fertile particles since there are penalties associated with crossover from fissile to fertile and vice versa (Ref. 2).

The pilot plant is also expected to deal with Fort St. Vrain (FSV) fuel. Both the fissile and the fertile FSV particles have TRISO coatings; therefore, after particle classification, both fractions are crushed and burned separately. 


\section{SOLIDS HANDLING SYSTEM DESIGN}

\subsection{DESIGN DESCRIPTION AND QUALIFICATION}

The solids handling system is divided into six subsystems (Fig. 5):

Subsystem No. 1 - crusher product removal system

Subsystem No. 2 - primary burner feed system

Subsystem No. 3 - primary burner product removal system

Subsystem No. 4 - particle classifier feed system

Subsystem No. 5 - particle crusher feed system

Subsystem No. 6 - secondary burner product removal system

Each of these subsystems is required to receive material from the preceding operation, transport it, store it, weigh it, recover it from storage, and feed it to the next step.

Pneumatic conveying is used to transport material. The blowers are at the ends of the conveying lines, such that the pressure in the system is below atmospheric. Solids are separated from the conveying gas with in-bunker filters. Valves in the conveying lines and off-gas lines and at bunker outlets isolate the bunkers. Electronic load cells weigh the bunker contents. High-level alarms in the walls of the bunkers are to prevent overfilling.

The initial activities in the solids handing system have been concerned with qualification testing, which can be defined as partial verification of the design using simulated feed. Complete verification will follow when loaded fuel elements are reprocessed in sequential operation. 


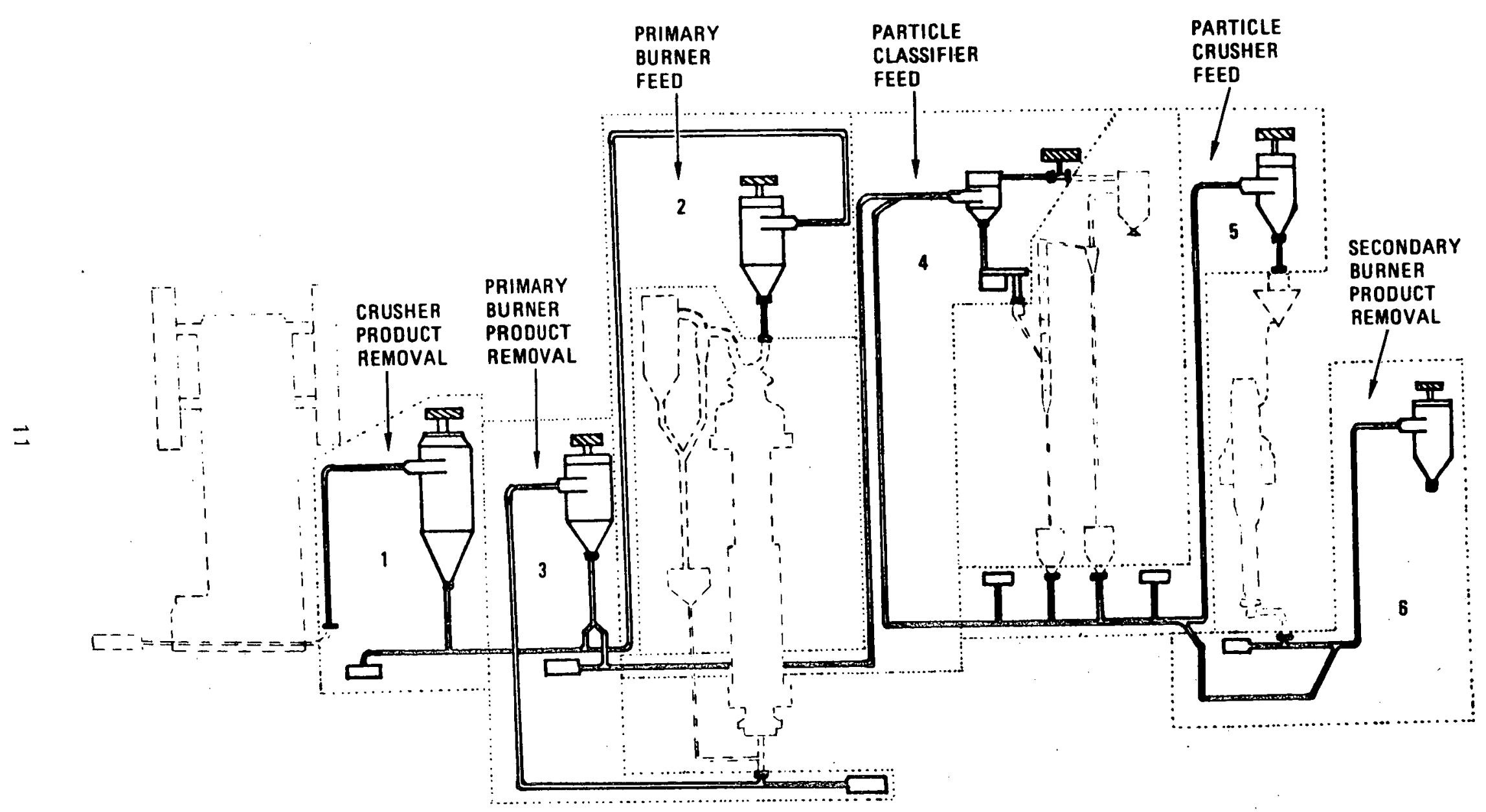

Fig. 5. Solids handling subsystems 
The qualification testing was divided into two phases: component testing followed by subsystem testing. Component testing is concerned with confirming the suitability of the equipment selected for the pilot plant. Subsystem testing is process oriented and is concerned with conveying system capacities and fuel particle breakage.

\subsection{DESIGN CRITERIA}

The basic cold pilot plant criterion for the solids handling system is that it must serve the needs of the other unit operations with minimal particle breakage. The system was not designed to be prototypical of a hot cell pilot plant. No efforts were made, for instance, to accommodate features such as radiation resistant components, remote maintenance, criticality, and fission product decay heat removal. Criteria for individual components of the system are discussed in the following sections.

\subsubsection{Inlet Filters}

The pressure drop across the filters at the inlets of the conveying lines should not be excessive. The filters should retain material in the line during upset, as well as normal, conditions.

\subsubsection{Conveying Lines}

The conveying lines should be adequately sized for the required system capacity. (This can only be determined during system testing.)

\subsubsection{Bunkers}

The bunker vessels must be able to withstand $59 \mathrm{kPa}(-6 \mathrm{psig})$ and $107 \mathrm{kPa}$ (+1 psig) pressures. (This was confirmed during component checkout.) The bunkers must discharge their contents and achieve cleanout to within $0.23 \mathrm{~kg}(0.5 \mathrm{lb})$. They must provide storage with a capacity suited to the requirements of the unit operations, as follows: 

No. 1 - crusher product bunker
4.6 fuel elements
No. 2 - primary burner feed bunker
0.9 fuel elements
No. 3 - primary burner product bunker
$270 \mathrm{~kg}$
No. 4 - classifier feed bunker
9.1 fuel elements
No. 5 - particle crusher feed bunker
$60 \mathrm{~kg}$
No. 6 - secondary burner product bunker
$60 \mathrm{~kg}$

\subsubsection{In-Bunker Filters}

In order to protect the positive displacement blowers, the filters must retain all particles greater than $5 \mu \mathrm{m}$. The blowback mechanism must be effective enough, after the filters have been preloaded, to retain a pressure drop across the filters within $5 \%$ of the non-preloaded pressure drop.

\subsubsection{Blowers}

The blowers must compress sufficient air to convey the desired throughputs of the conveying systems. (This can only be determined during system testing.)

\subsubsection{Leve1 Sensors}

The level sensors are required to provide a signal when the contents of a bunker reach a predetermined level and to stop providing such a signal when the contents are reduced.

\subsubsection{Feeders}

The feed rate to each of the conveying systems must be within the capacity of the system. The rate at which material is fed to a unit operation must be compatible with that operation. Specific requirements are: 
Primary burner feeder: must be calibrated over the entire rotating range with burner feed. An accuracy of $\pm 5 \%$ is desirable.

Particle classifier feeder: must be calibrated using both TRISO and BISO/TRISO fuel particles. Maximum capacity is $1.5 \mathrm{~kg} / \mathrm{min}$. There are no specific accuracy requirements.

\subsubsection{Weigh Cells}

The weigh cells are to be calibrated with accurate weights $( \pm 0.1 \%)$ and must give an accuracy of $\pm 0.5 \%$ of the design basis load. The repeatability must be within $\pm 0.1 \%$ of the design basis load. 


\section{MAJOR COMPONENT TESTING}

In this section, each component is described together with related tests, if any, and the criteria for acceptance.

\subsection{INLET FILTERS}

\subsubsection{Description}

At the beginning of each pneumatic transport line, there is a HEPA filter (Fig. 6). In order to prevent damage from above, a protective plate is placed over the inlet to the filter. These filters serve two purposes: to prevent stray particulates from entering the line and, in the event of a mishap, to prevent particulate material from leaving the line. It is important to verify the latter capability.

\subsubsection{Testing}

The pressure drop across the inlet filters of the various transport systems was measured so that future degradation of filter performance can be monitored. The filters were tested individually on the same transport system so that results could be compared directly. The results were disappointing since the measured pressure drops exceeded the manufacturer's rated pressure drop values in all cases. This is presumably caused by the contraction in flow area (from a diameter of $0.30 \mathrm{~m}$ to 0.048 or $0.035 \mathrm{~m}$ ). The pressure drop data are given in Table 1. Although the inlet filters presently do not pose a significant hindrance to transport system operation, they do somewhat reduce the total system capacities. The filters will be studied closely during future operation of each individual system to determine the specific impact on the performance of each system. 
TABLE 1

MEASURED PRESSURE DROP ACROSS INLET FILTERS

\begin{tabular}{|c|c|c|}
\hline Inlet Filter Location & $\begin{array}{c}\Delta \mathrm{P} \text { Measured } \\
\left(\mathrm{Pa} \text { at } 212.3 \mathrm{~m}^{3} / \mathrm{h}\right)\end{array}$ & $\begin{array}{c}\Delta \mathrm{P} \text { Rated } \\
\left(\mathrm{Pa} \text { at } 424.7 \mathrm{~m}^{3} / \mathrm{h}\right)\end{array}$ \\
\hline Fuel element size reduction system & 1145 & $23 \hat{4}$ \\
\hline Crusher product bunker & 1071 & 229 \\
\hline Primary burner & 1170 & 229 \\
\hline Secondary burner & 1071 & 234 \\
\hline Primary burner product bunker ${ }^{(a)}$ & 1942 & 239 \\
\hline Fissile classifier product burner ${ }^{(a)}$ & 1868 & 239 \\
\hline Fertile classifier product bunker ${ }^{(a)}$ & 2141 & 234 \\
\hline Spare filter & 1195 & 239 \\
\hline
\end{tabular}

(a) $0.035-\mathrm{m}$ filter outlet; a11 others are $0.048 \mathrm{~m}$. 
During the first dump of product from the secondary burner into the secondary burner product removal system (subsystem No. 6), material flowed backwards, against the gas flow, and down into the inlet filter, which was below the level of the burner outlet and pointing downward. The outside of the filter was subsequently examined for evidence of radioactivity. None was observed. Since secondary burner product is the finest material the the solids handling system needs to convey (mean size $\simeq 50 \mu \mathrm{m}$ ), it can be concluded that the inlet filters adequately perform the function of containing material. In subsequent secondary burner product removals, the filter was installed pointing upward and at a height close to the level of the fluid bed. This is intended to prevent fluidized material from entering the filter under "hydrostatic" pressure.

\subsubsection{Acceptability}

Although the pressure drops across the filters are higher than the manufacturer's rated pressure drop values, they are acceptable. Only extended operation will yield information about useful lifetimes. Complete retention of material in the conveying line during upset conditions was observed.

\subsection{CONVEYING LINES}

\subsubsection{Description}

The conveying lines are stainless steel with internal diameters of 0.048 and $0.035 \mathrm{~m}$. The smaller size is used for conveying fuel particles from the classifier product bunkers to the particle crusher feed bunker and the secondary burner product bunker. The lines are divided into manageable lengths, which are held together with clamps. The bends are gradual (bend radius $=0.56 \mathrm{~m}$ ) in order to reduce particle breakage. The first bend in each subsystem is placed as far away from the solids inlet as possible, in order to allow the conveying mixture to accelerate prior to the deceleration in the bend. Just before the end of each conveying line there is a bunker inlet valve, which isolates the bunker; a bellows, needed 
for weigh cell accuracy; and an expansion in the line diameter. This expansion is intended to begin slowing down the conveyed particles. The tangential entry to the bunker prevents perpendicular impingement of particulates on metal walls or filter surfaces (Fig. 7).

\subsubsection{Future Testing}

As a conveying line erodes, bends usually suffer the worst effects. The rate of erosion is of interest. U1trasonic measurement techniques are currently under study for use in monitoring possible bend erosion of the pneumatic transport tubing.

\subsection{BUNKERS}

\subsubsection{Description}

The bunkers perform storage, weighing, dosing, and pneumatic transfer receiving functions. They were sized conservatively; i.e., the top surface of the bed was assumed to be concave. They are designed to discharge the entire contents and to withstand 107 and $59 \mathrm{kPa}$ pressures. A pressure relief valve opens at $107 \mathrm{kPa}$, and in the event that the valve fails, a bursting disk is available. The 59-kPa pressure is relieved at the blower. Three bunkers (crusher product, primary burner feed, and secondary burner product bunkers) are equipped with aerated bottoms (Fig. 8). Gas flows via a flowmeter through a woven steel mesh cone, so that the bunker contents are loosened and can flow easily.

Secondary burner product is a fine, cohesive material requiring assisted discharge from containers. Crusher product and primary burner feed are comprised of crushed graphite and fuel particles. Although this material is free flowing when thoroughly mixed, problems can occur. As the suspended particles leave the pneumatic conveying line and enter a bunker, coarse particles drop down and fines remain in suspension, circulating around the in-bunker filters. When transport is stopped, these fines settle as a 


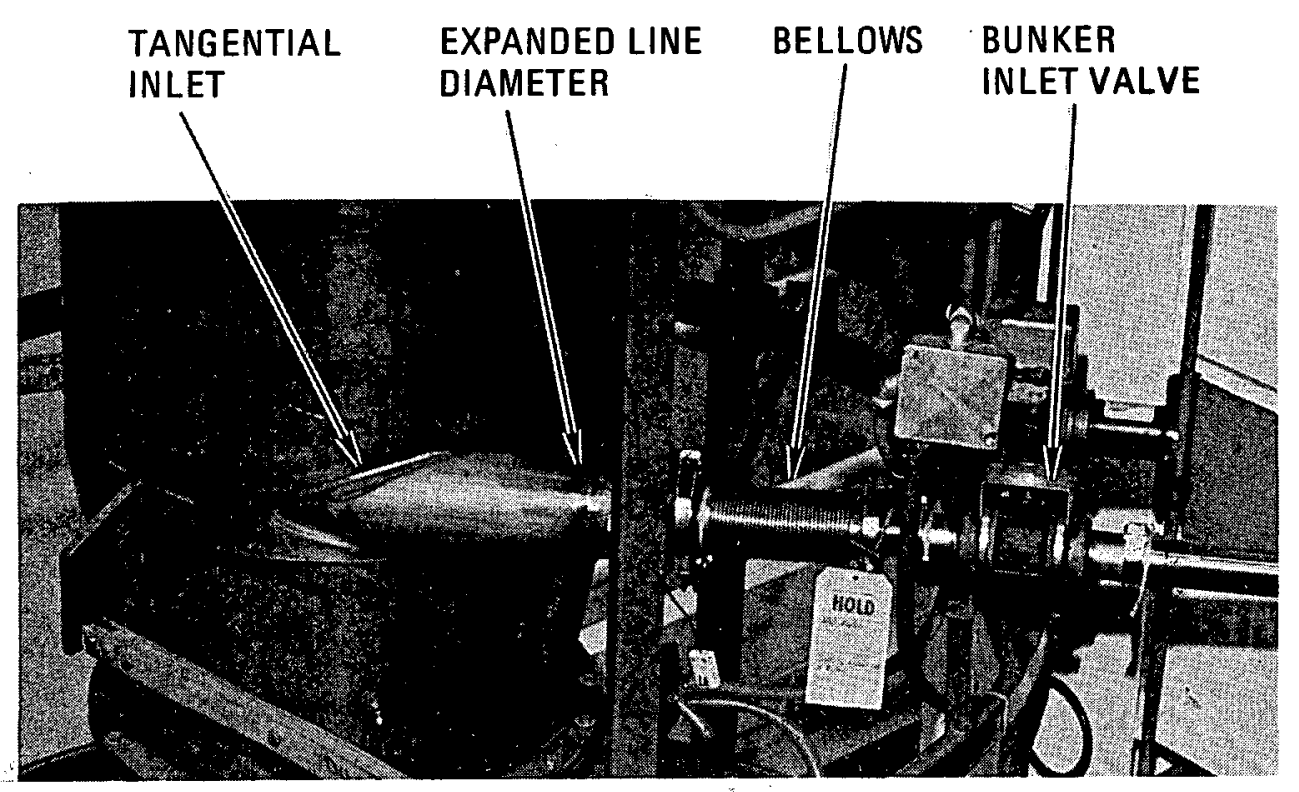

Fig. 7. End of a pneumatic conveying line $[5.08 \mathrm{~cm}$ (2 in.) conveying line expanding to $10.16 \mathrm{~cm}$ (4 in.); $63.50 \mathrm{~cm}$ (25 in.) diameter bunker] 


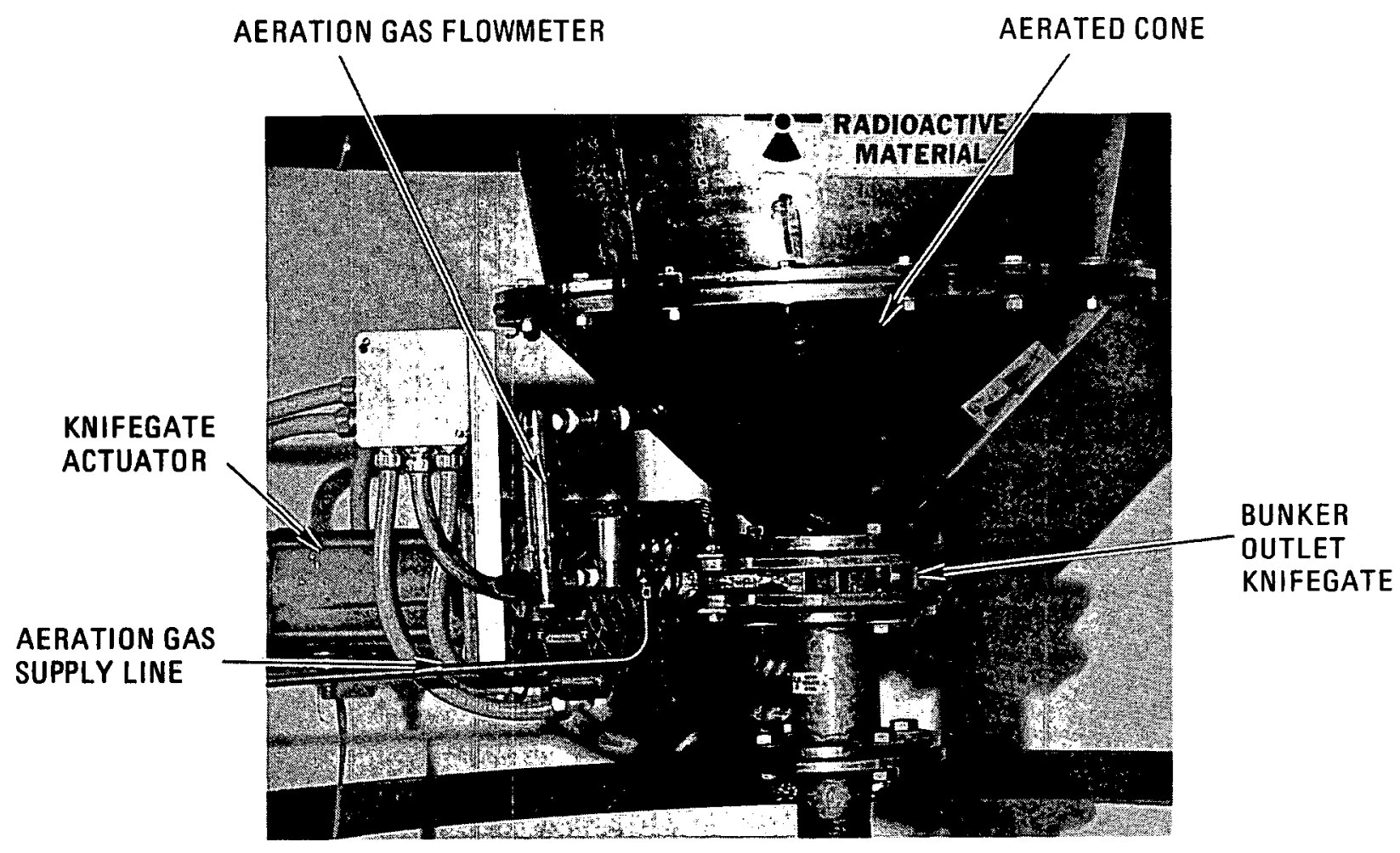

Fig. 8. Aerated cone and bunker outlet [5.08 cm (2 in.) diameter] 
layer on top of the other contents. When this layer reaches the outlet, cohesive bridging can occur. Hence discharge assistance was provided on the crusher product and primary burner feed bunkers with aerated cone bottoms.

\subsubsection{Testing}

\subsubsection{Test Procedure. Apart from demonstrating that design basis} materials freely discharge from the bunkers, the volume of material required to activate the high-level alarms needs to be determined experimentally. The method employed to calculate the volume is to measure the height of material in a drum, which is fed into the conveying line leading to the bunker in question. This is repeated until the alarm is activated. Material is then discharged from the bunker until the alarm stops. The mean volume is used. The load cell signals can be used to measure the bulk density.

In the case of the secondary burner product bunker, which has no leve 1 sensors, the volume has to be calculated based on results from other bunkers.

\subsubsection{Test Results. No problems were encountered when discharging} crushed graphite through a $0.05-\mathrm{m}$ orifice from the crusher product bunker, the primary burner feed bunker, and the primary burner product bunker. A simulated feed mixture consisting of crushed graphite and BISO and TRISO fuel particles discharged from the primary burner feed bunker at a rate controlled by the rotary feeder valve beneath. BISO and TRISO fuel particles discharged at respective rates also determined by the rotary feeder valve.

TRISO fuel particles discharged through a $0.025-\mathrm{m}$ orifice from the primary burner product hopper, but did not flow through a 0.019-m orifice due to an accumulation of fines just above the orifice. BISO fuel particles discharged through the 0.019-in. orifice. Such difficulties are discussed further under Section 4.7, Feeders. 
BISO and TRISO fuel particle types discharged from the classifier feed bunker at rates controlled by the classifier vibratory feeder.

TRISO fuel particles discharged from the particle crusher feed bunker at a rate controlled by the roll crusher beneath.

Secondary burner product flowed easily out of the 0.05-m secondary burner product bunker outlet with the aid of the aerated bottom cone of the bunker. Any restriction below the bunker outlet results in a bridge.

The solids handing system bunker volumes were determined by a combination of experimental and analysis methods. The original design volume, as calculated, was found to be conservative. Since feed material enters a bunker tangentially, the material was assumed to fill from the bunker walls inward, declining in height as a function of the material's angle of repose. Calculations of bunker volumes under these assumptions were conservative, assuring that actual bunker volumes would be greater than the minimum required by the design criteria.

The actual volumes of three bunkers were determined experimentally by filling the bunkers with known volumes of crushed graphite until the highlevel sensors signalled. Upon inspection, the material was found to be deposited in a uniform, nearly flat configuration, as shown in Fig. 9. This material configuration closely approximates the actual internal bunker volume as calculated up to the top of the high-level sensors. From these results, the volumes of the remaining bunkers were determined by calculation. The volumes of these remaining bunkers are probably still conservative to some degree, because fuel particles have a low angle of repose and will tend to deposit within a bunker in a level configuration, even more so than crushed graphite, allowing a slightly larger portion of the bunker to be filled. Results of the bunker volume experiments and volume calculations are compared in Table 2. 


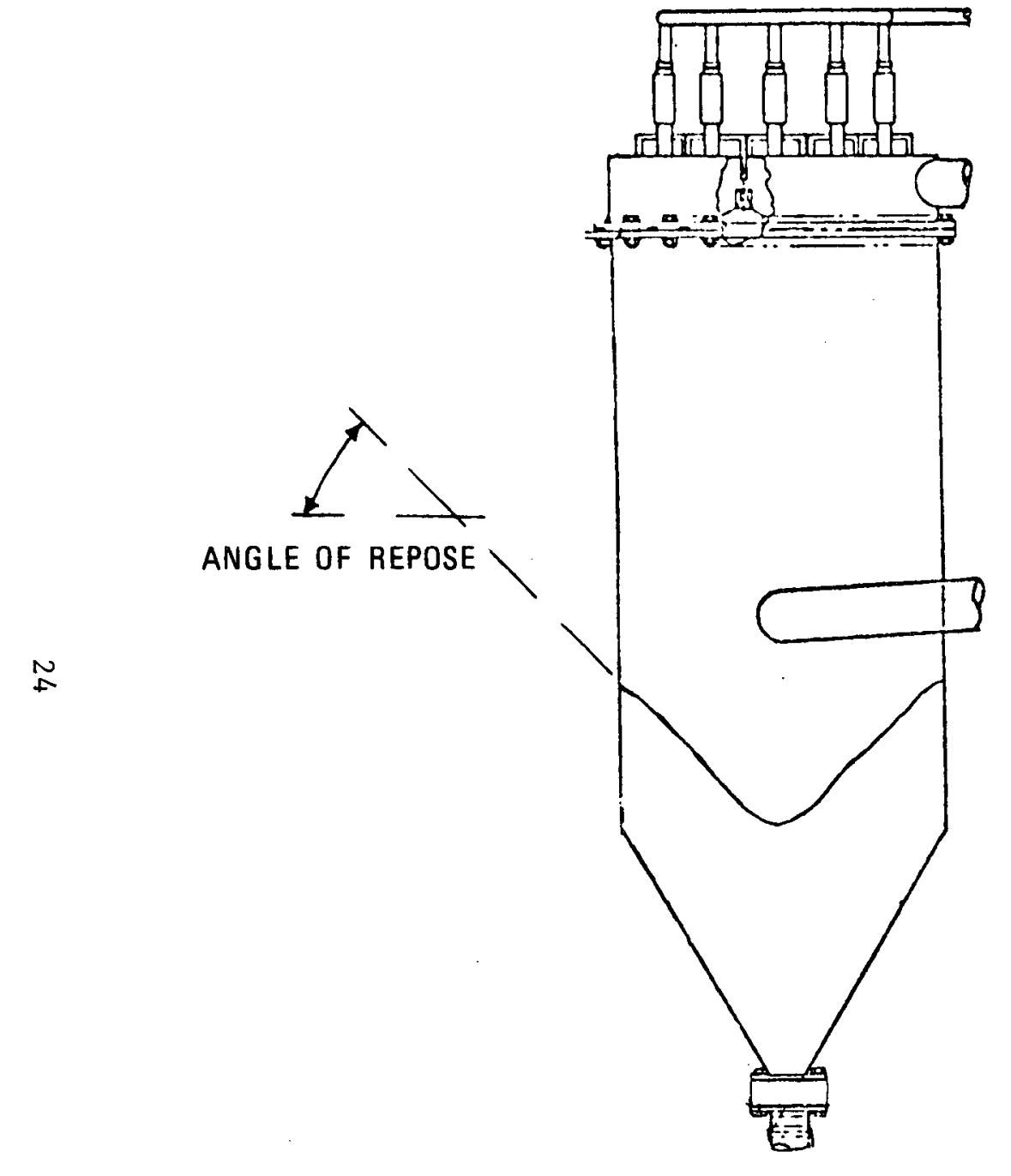

DESIGN VOLUME CONFIGURATION

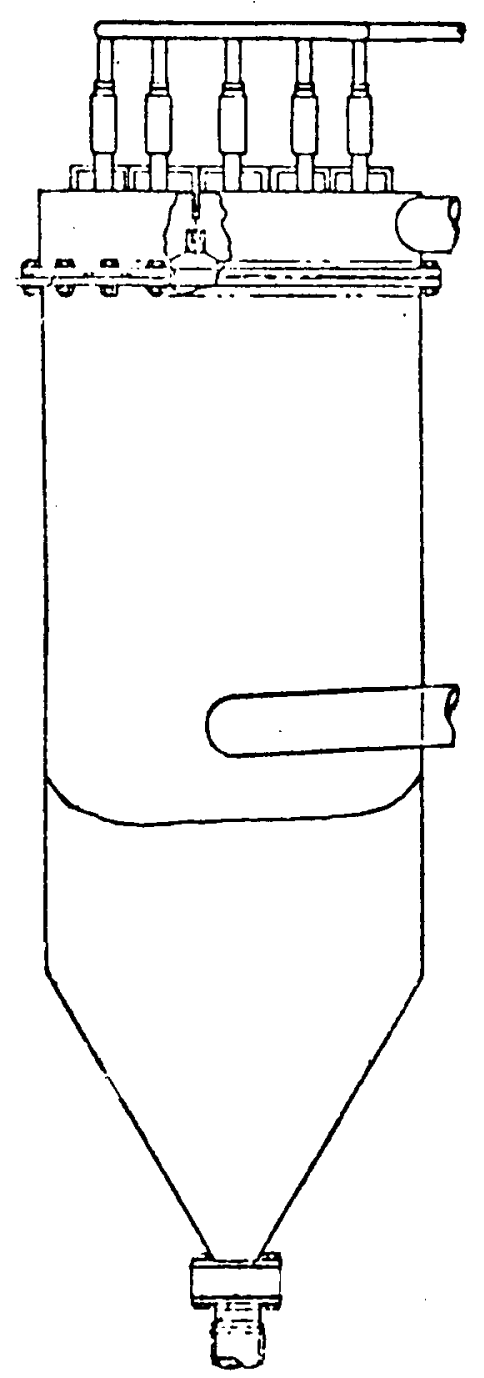

ACTUAL VOLUME CONFIGURATION

Fig. 9. Design and actual solids handling system bunker volumes 
TABLE 2

EFFECTIVE BUNKER VOLUMES

\begin{tabular}{c|c|c|c}
\hline Bunker & $\begin{array}{c}\text { Design Volume } \\
\left(\mathrm{m}^{3}\right)\end{array}$ & $\begin{array}{c}\text { Experimenta1ly } \\
\text { Determined Volume } \\
\left(\mathrm{m}^{3}\right)\end{array}$ & $\begin{array}{c}\text { Volume } \\
\text { Below Top } \\
\text { of Sensor } \\
\left(\mathrm{m}^{3}\right)\end{array}$ \\
\hline $\begin{array}{c}\text { Crusher product } \\
\text { Primary burner } \\
\text { product }\end{array}$ & 0.550 & 0.736 & 0.790 \\
$\begin{array}{c}\text { Primary burner } \\
\text { feed }\end{array}$ & 0.136 & 0.283 & 0.252 \\
$\begin{array}{c}\text { Classifier feed } \\
\text { Particle crusher } \\
\text { feed }\end{array}$ & 0.110 & 0.150 & 0.158 \\
$\begin{array}{c}\text { Secondary burner } \\
\text { product }\end{array}$ & 0.034 & Has no level & 0.130 \\
\hline
\end{tabular}


The original equipment qualification plans included filling the classifier and particle crusher feed bunkers with design basis materials until the high-level alarms were activated. Since the volume of material required can be estimated with a fair degree of certainty, such experiments are not required. Furthermore, a severe strain on the avallable fuel particle inventory would have resulted.

\subsubsection{Acceptability}

4.3.3.1. Discharge. The design basis materials flowed out of the bunkers. Improvements to avoid having to change the size of the discharge opening with different fuel particles are discussed further under Section 4.7, Feeders. The completeness of the discharge was demonstrated during the in-bunker filter testing (see Section 4.4, In-Bunker Filters).

\subsubsection{Capacities. The design requires bunker capacities as follows:}

\section{Subsys tem}

No. 1 - crusher product bunker

No. 2 - primary burner feed bunker

No. 3 - primary burner product bunker

No. 4 - classifier feed bunker

No. 5 - particle crusher feed bunker

No. 6 - secondary burner product bunker

\section{Capacity}

4.6 fuel elements

0.9 fuel element

$270 \mathrm{~kg}$

9.1 fuel elements

$60 \mathrm{~kg}$

$60 \mathrm{~kg}$

These capacities, with the approximate bulk densities of the design basis material to be deposited in each of the respective bunkers, were used to calculate the design volume of each bunker as given in Table 2. The actual bunker capacities are acceptable for all bunkers. 


\subsection{IN-BUNKER FILTERS}

\subsubsection{Description}

Porous stainless steel filter pipes (Fig. 10) are used inside the bunkers to separate the gas and solids received from the pneumatic conveying lines. These filters have a mean pore size of $5 \mu \mathrm{m}$ and are intended to prevent particles larger than $5 \mu \mathrm{m}$ from entering the blowers, where they could damage the rotors. The filters are cleaned by a reverse flow of high-pressure $\mathrm{CO}_{2}$, which is distributed through a manifold and cam-timercontrolled solenoid valves (Fig. 11). Both the $\mathrm{CO}_{2}$ supply line and the filter exhaust line have bellows connections, as required by the load cells. In order to observe the pressure drop across the filters, a differential pressure gauge is installed on each bunker. The pressure tap on the bunker also serves as an inlet for argon from the argon dump system, which was installed to prevent hazards arising from the pyrophoric nature of some fuel particle kernels (Fig. 12).

\subsubsection{Testing}

4.4.2.1. Test Procedure. The test procedure is intended to verify that the filters prevent particles greater than $5 \mu \mathrm{m}$ leaving the bunker, to verify that the pressure drop is acceptable, and to preload the filters so that material entering the bunker can be recovered. The steps are:

1. Using the test-rig variable speed blower, measure the pressure drop across the filters at $30 \%, 60 \%$, and $90 \%$ power.

2. With the gas flow at $90 \%$ power, introduce approximately $3 \mathrm{~kg}$ of graphite fines into the conveying line. Note the weight added. For the secondary burner product bunker, fine silicon carbide was used. 


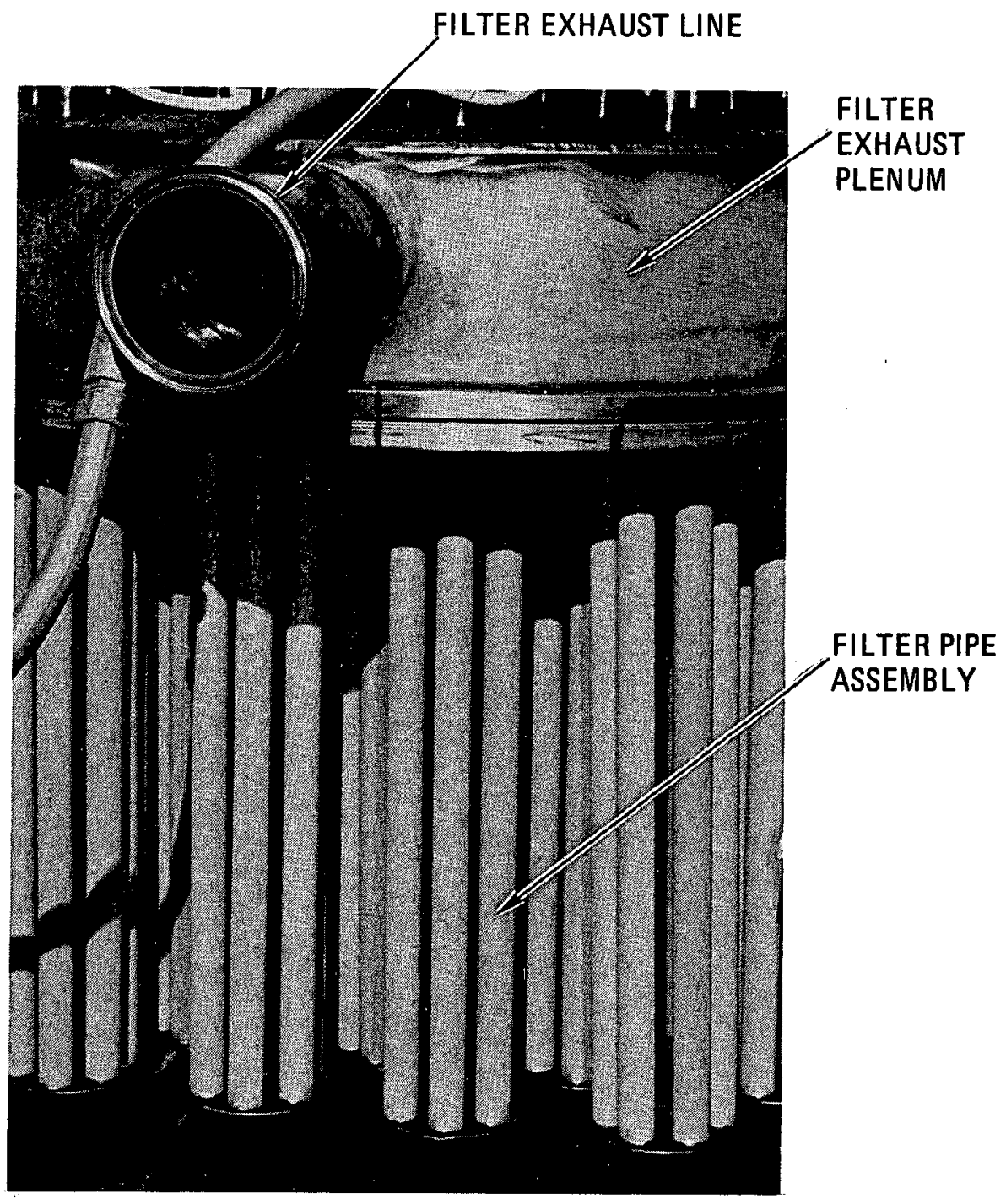

Fig. 10. Porous stainless steel in-bunker filter pipes $[2.54 \mathrm{~cm}$ (1 in.) diameter pipes in groups of six] 


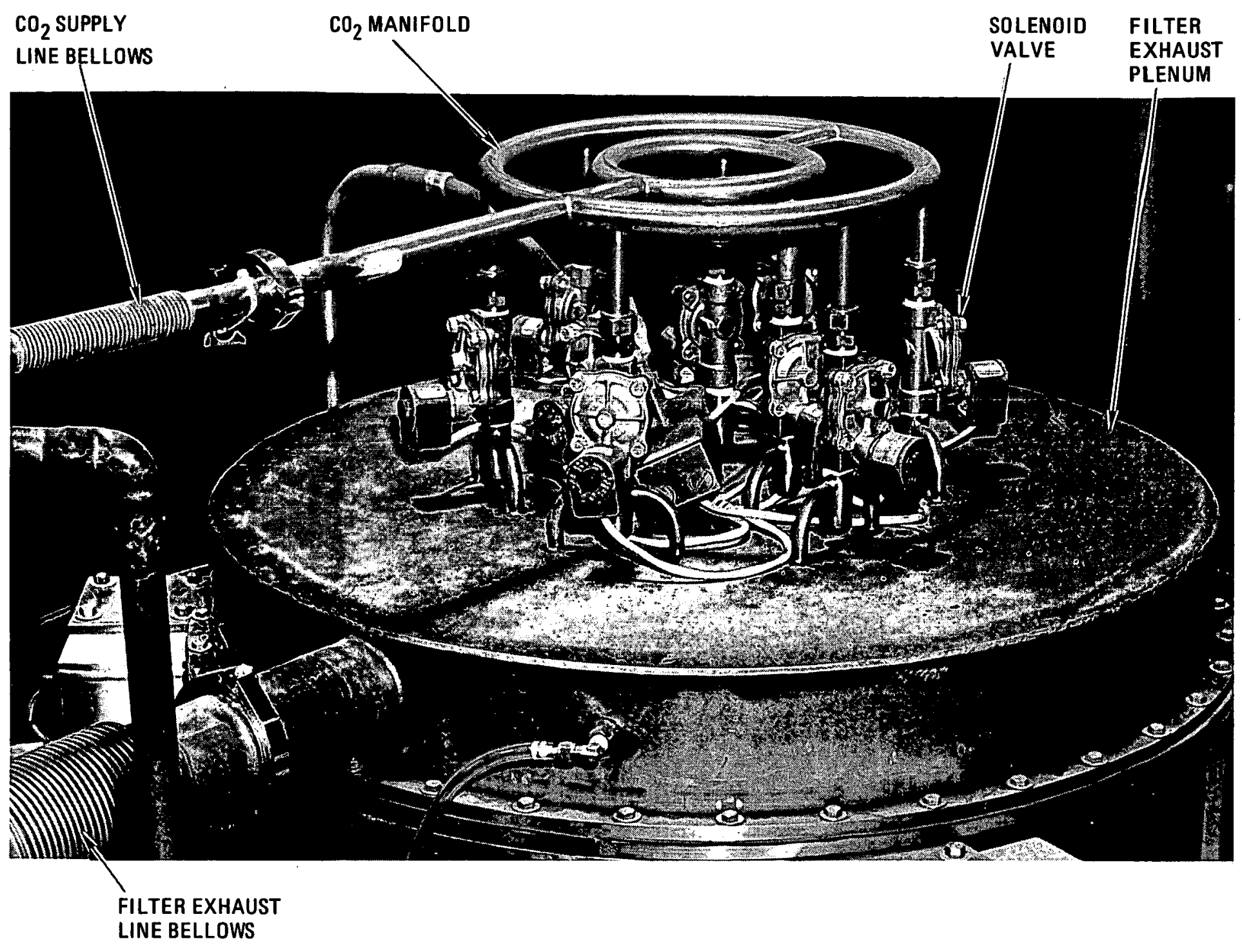

Fig. 11. In-bunker filter blow-back assembly $[91.44 \mathrm{~cm}$ (36 in.) diameter bunker] 


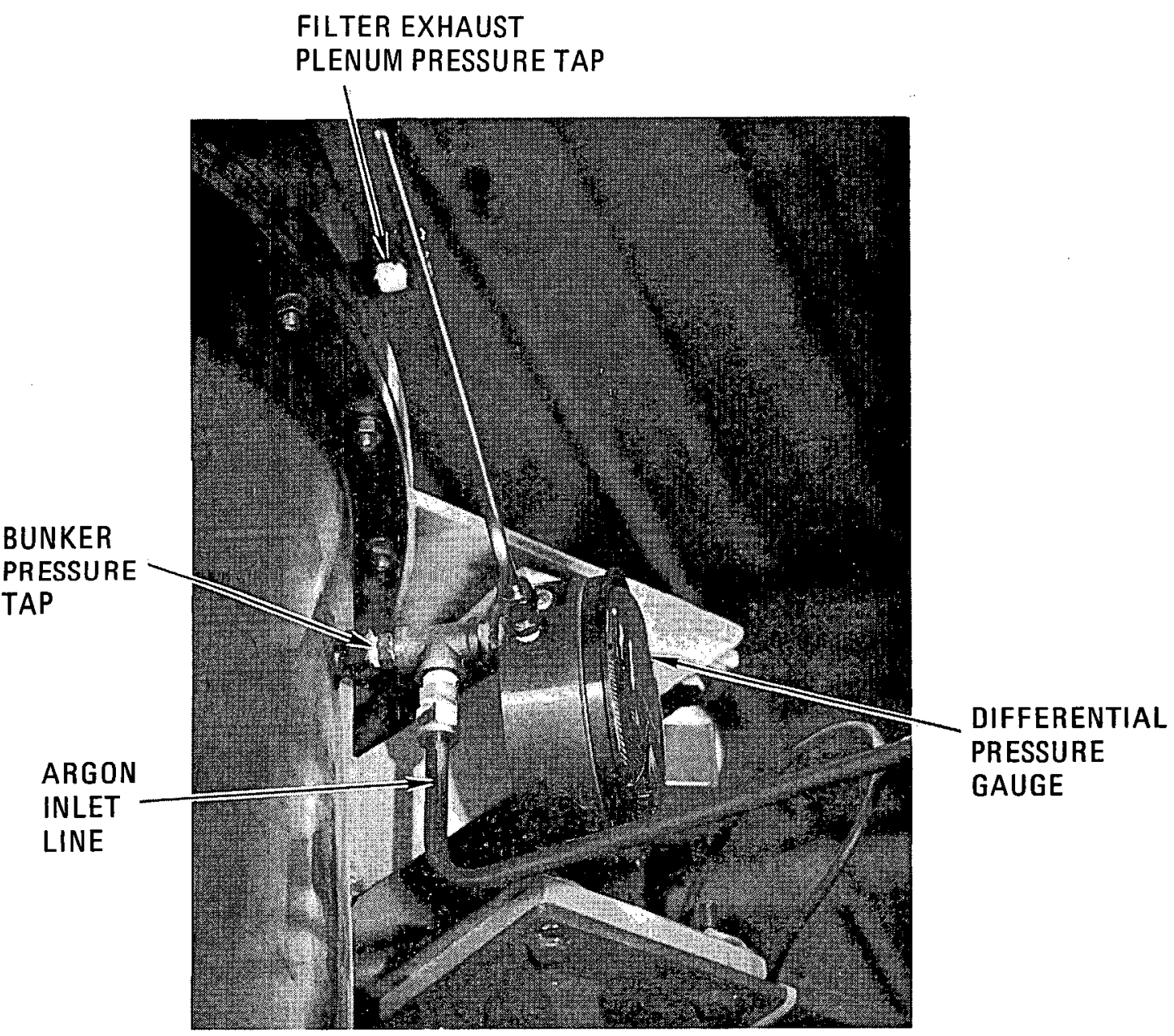

Fig. 12. In-bunker filter pressure drop measurement arrangement and argon inlet line 
3. With the blower off, actuate one complete blowback cycle. Restart blower and measure pressure drop. Repeat with 10 complete blowback cycles. Remove blown-back fines and calculate weight on the filters.

4. Repeat steps 2 and 3 until 95\% of the fines going in are recovered.

5. Before and after the tests, take a sample wipe from the inside of the filter exhaust line and analyze for particle size distribution.

4.4.2.2. Test Results. Verification of the ability of filters to clean conveying gas is based on a statistical argument. All of the in-bunker filters have been tested. The sample wipes, taken before and after testing from the inside of the filter exhaust bellows, were examined by photographing a strip across the wipe at $120 \mathrm{X}$ magnification. The particles were counted according to size. Two sizes were used - greater than or less than $1 / 2 \mathrm{~mm}$ on the photographs, which corresponds to $4.2 \mu \mathrm{m}$. The results of the wipes are shown in Table 3. Application of the "t-test" shows that the percentages of particles below $4.2 \mu \mathrm{m}$ from before and after loading the filters are not significantly different. Since particles coming through the filters can be expected to be deposited to some extent, and since the deposited particles present before the filter loading can be assumed not to have been lifted off during the testing, it can be concluded that no significant quantities of particles are passing through the filters.

During operation of the secondary burner product removal system, a rupture disc downstream of the bunker burst. Subsequently, the blower inlet filter was dismantled, with no trace of radioactivity revealed. Secondary burner product is one of the finest powders present in the headend process (average size of $50 \mu \mathrm{m}$ ) and is radioactive. This finding further verifies the effectiveness of the in-bunker filters. 
TABLE 3

SIZE DISTRIBUTION OF SAMPLE WIPES

\begin{tabular}{c|c|c}
\hline & $\begin{array}{c}\text { Total Number of Particles } \\
\text { on Photographs }\end{array}$ & $\begin{array}{c}\text { Percentage } \\
\text { above 4.2 } \mu \mathrm{m}\end{array}$ \\
\hline Subsystem No. 1 & 1764 & 55.8 \\
Before testing & 3496 & 43.1 \\
After testing & & \\
Subsystem No. 2 & 1465 & 20.8 \\
Before testing & 389 & 45.2 \\
After testing & & \\
Subsystem No. 3 & 344 & 58.2 \\
Before testing & 709 & 58.0 \\
After testing & & 60.2 \\
Subsystem No. 4 & 1204 & 32.3 \\
Before testing & 648 & \\
After testing & & 48.6 \\
Subsystem No. 5 & 1563 & 50.1 \\
Before testing & 1687 & \\
After testing & & 59.1 \\
Subsystem No. 6 & 962 & 55.5 \\
Before testing & 247 & \\
After testing & & \\
\hline
\end{tabular}

Mean percentage above $4.2 \mu \mathrm{m}$, before testing $=50.5 \%$

Mean percentage above $4.2 \mu \mathrm{m}$, after testing $=47.4 \%$

Difference in the means

$=3.1 \%$

Joint estimate of the standard deviation

$=12.3 \%$ 
More definite verification of filter performance could be obtained by installing a sampling/filtering system in the off-gas line of one of the more frequently used systems.

The pressure drop and holdup results for all systems are given in Table 4. No more than one repeat was required to bring the holdup down to acceptable levels.

\subsubsection{Acceptability}

4.4.3.1. Recovery. The design calls for $>95 \%$ after preloading; $5 \%$ of the fines used (2120 to $3129 \mathrm{~g}$ ) ranges from 106 to $156 \mathrm{~g}$. Reference to Table 4 shows that this design criterion is satisfied. The ability to clean out the bunkers to within $250 \mathrm{~g}$ is similarly verified (see Section 4.3, Bunkers).

4.4.3.2. Pressure drop. The design calls for $<10$ in. water clean and $<20$ in. water blown back. Table 4 shows that the pressure drops measured are well within the limits.

4.4.3.3. Efficiency. The design calls for $100 \%$ efficiency for particles greater than $5 \mu \mathrm{m}$. Unless gas sampling or tracer techniques are used downstream of the filters, it is difficult to prove $100 \%$ efficiency explicitly. The implicit results satisfy the criterion.

\subsection{BLOWERS}

The rotary blowers are mounted in frames (Fig. 13), together with an electric motor, an inlet filter, an outlet filter, an underpressure relief valve set at $40 \mathrm{kPa}$ (12 in. $\mathrm{Hg}$ ), and a pressure gauge, which also registers in the control room. Except for the variable-speed classifier blower, the blowers are fixed-speed units. The major goal of the system testing is to establish a suitable speed for permanent operation. The gas, after compression, goes to a central vent system. 
TABLE 4

FILTER LOADING TESTS

\begin{tabular}{|c|c|c|c|c|c|c|c|c|c|c|c|c|}
\hline & \multicolumn{2}{|c|}{ Subsystem 1} & \multicolumn{2}{|c|}{ Subsystem 2} & \multicolumn{2}{|c|}{ Subsystem 3} & \multicolumn{2}{|c|}{ Subsys tem 4} & \multicolumn{2}{|c|}{ Subsystem 5} & \multicolumn{2}{|c|}{ Subsystem 6} \\
\hline & $1^{(a)}$ & 2 & 1 & 2 & 1 & 2 & 1 & 2 & 1 & 2 & 1 & 2 \\
\hline $\begin{array}{l}\Delta \mathrm{P} \text { (clean filter, } \\
30 \% \text { power }) \text {, in. } \mathrm{H}_{2} \mathrm{O}\end{array}$ & 0.6 & & 1.2 & & 1.0 & & 0.8 & & 0.5 & & 0.5 & \\
\hline $\begin{array}{l}\Delta \mathrm{P} \text { (clean filter, } \\
60 \% \text { power), in. } \mathrm{H}_{2} \mathrm{O}\end{array}$ & 1.8 & & 2.5 & & 1.8 & & 1.9 & & 2.0 & & 1.7 & \\
\hline $\begin{array}{l}\Delta \mathrm{P} \text { (clean filter, } \\
90 \% \text { power }), \text { in. } \mathrm{H}_{2} \mathrm{O}\end{array}$ & 2.9 & & 3.5 & & 2.5 & & 2.8 & & 2.9 & & 2.5 & \\
\hline $\begin{array}{l}\Delta \mathrm{P} \text { (loaded filter, } \\
90 \% \text { power), in. } \mathrm{H}_{2} \mathrm{O}\end{array}$ & 3.1 & & 4.5 & & 2.8 & & 3.3 & & 3.0 & & 2.5 & \\
\hline $\begin{array}{l}\triangle \mathrm{P} \text { after one blowback } \\
\text { cycle, in. } \mathrm{H}_{2} \mathrm{O}\end{array}$ & 2.9 & & 3.5 & & 2.5 & & 3.3 & & 2.5 & & 2.5 & \\
\hline $\begin{array}{l}\triangle \mathrm{P} \text { after } 10 \text { blowback } \\
\text { cycles, in. } \mathrm{H}_{2} \mathrm{O}\end{array}$ & 2.9 & & 3.5 & & 2.5 & & 2.8 & 2.8 & 2.5 & 2.5 & 2.5 & 2.5 \\
\hline $\begin{array}{l}\text { Weight of fines } \\
\text { added, } \mathrm{g}\end{array}$ & 2725 & 3116 & 3233 & & 2997 & 2757 & 2315 & 2140 & 2589 & 2401 & 3077 & 2950 \\
\hline $\begin{array}{l}\text { Weight of fines } \\
\text { recovered, } g\end{array}$ & 2595 & 3239 & 3233 & & 2765 & 2736 & 2140 & 2120 & 2401 & 2310 & 2950 & 2936 \\
\hline Holdup, $g$ & 130 & -13 & 0 & & 232 & 21 & 175 & 20 & $188^{(b)}$ & $91^{\text {(b) }}$ & 112 & 14 \\
\hline
\end{tabular}

(a) Test number.

(b) Includes spillage. 


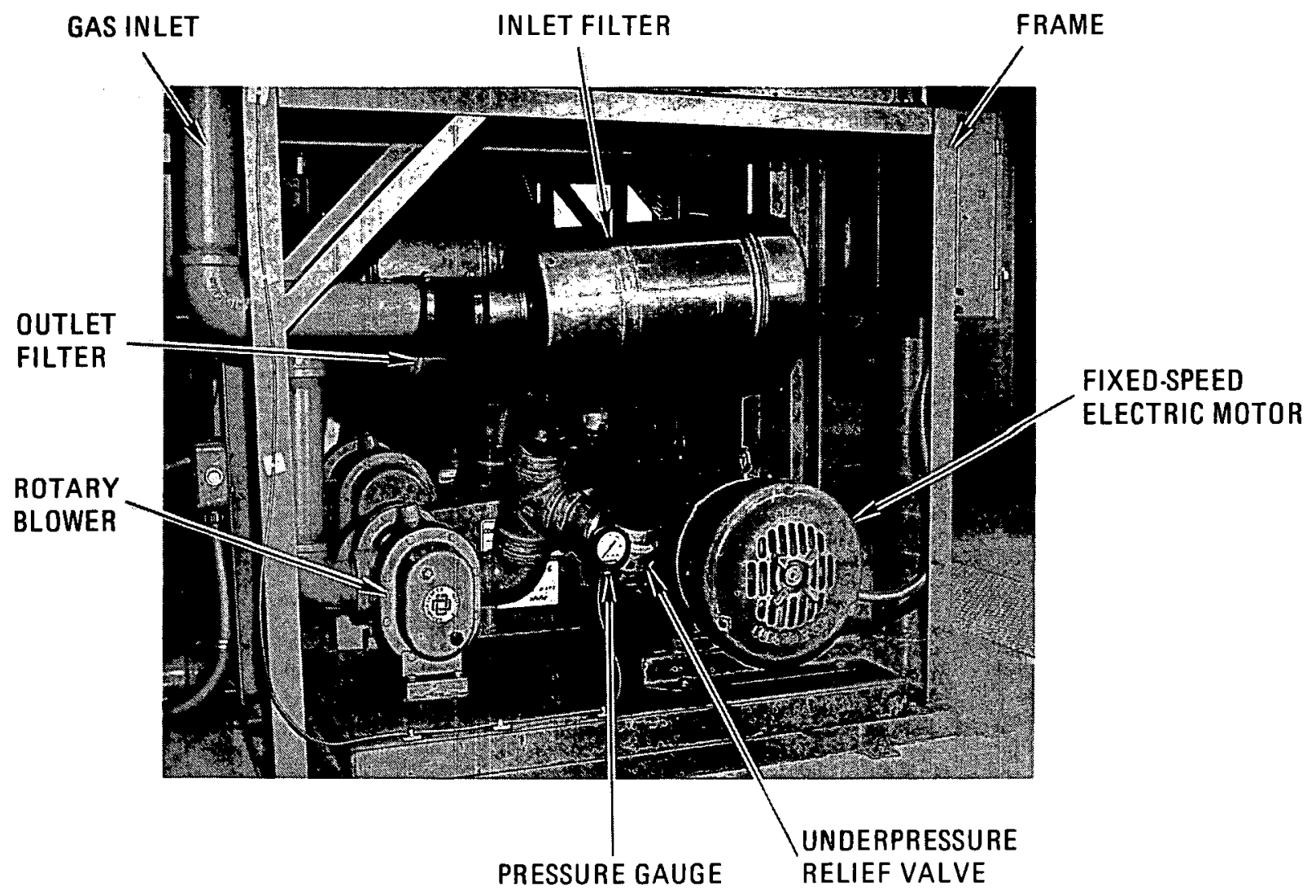

Fig. 13. Rotary blower used to provide moving air for pneumatic conveying 
The speed at which the blower rotates is controlled by the relative sizes of the sheaves, or pulleys, on the motor and blower shafts. The Gardner-Denver Company, which supplied the blowers, provides performance specifications for the relevant model (3PDR9) (Fig. 14). The data can be accurately described by the following formula:

$$
\frac{\mathrm{rpm}}{1000}=\frac{218 \mathrm{~V}+30+0.833 \mathrm{P}}{151-1.57 \mathrm{P}},
$$

where $\mathrm{rpm}=$ blower speed (revolutions/min),

$\mathrm{V}=$ gas volume flow rate $\left(\mathrm{m}^{3} / \mathrm{s}\right)$ (standard),

$\mathrm{P}=$ underpressure at blower inlet $(\mathrm{kPa})$.

This formula has been verified experimentally.

4.6. LEVEL SENSORS

4.6.1. Description

In order to prevent the overfilling of bunkers, level sensors are used. The principle involved is the interruption of an ultrasonic beam, which is propagated between two sensors. These sensors are placed just below the level at which the conveying line enters (Fig. 15). An alarm in the control room is activated when this level is reached, and the feeding of solids to the conveying line can be stopped automatically. Experimental determination of the capacity of the bunkers fitted with these devices (subsystems No. 1 through 5) is required.

\subsubsection{Testing and Acceptability}

During filling of the crusher product, primary burner feed, and product bunkers, the level sensors were activated satisfactorily and during emptying they were deactivated satisfactorily. During the discharge of fuel particles at $700^{\circ} \mathrm{C}$ from the primary burner, however, the high-level alarm in the primary burner product bunker was activated. Subsequent 


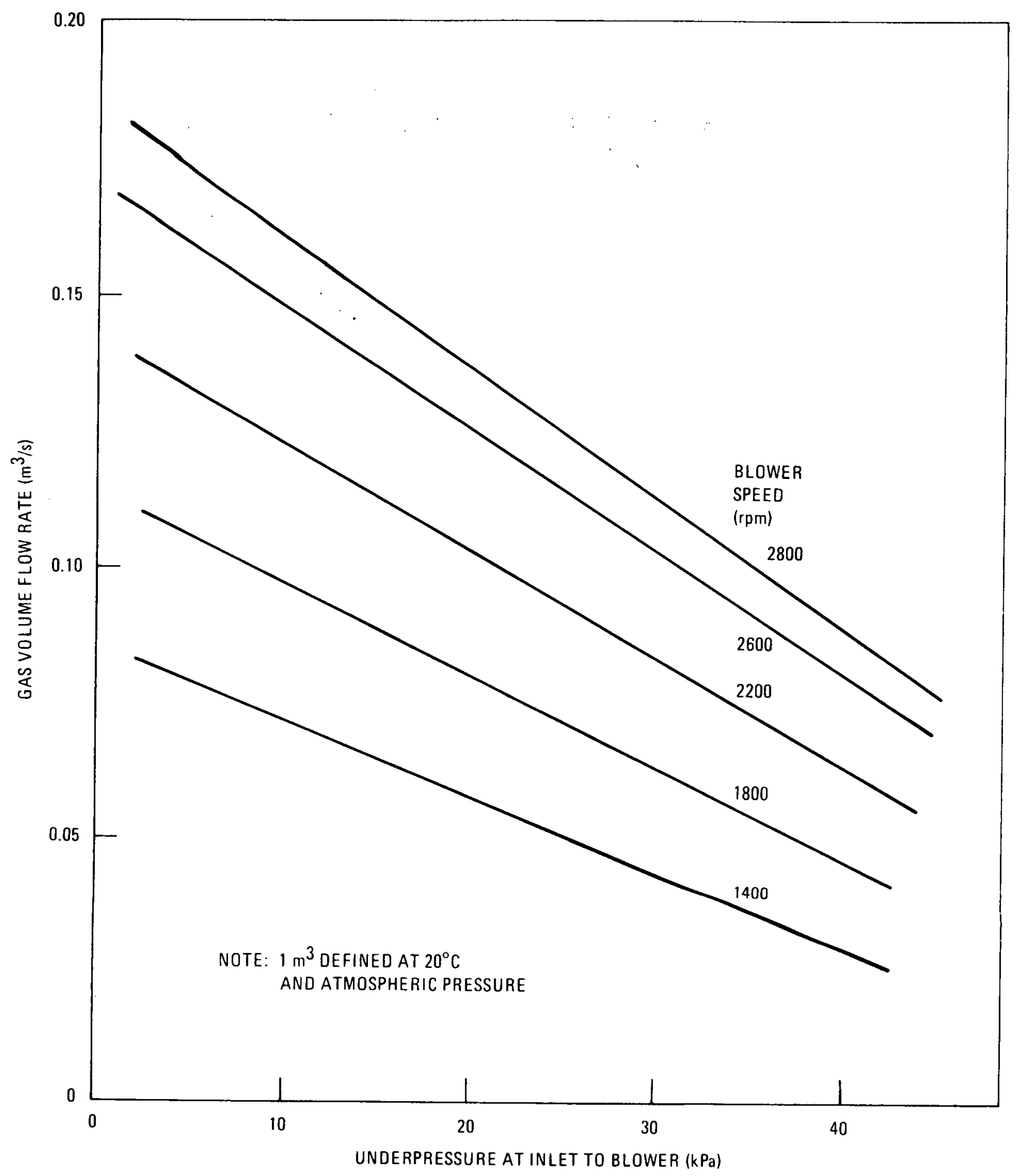

Fig. 14. Blower performance specifications (Gardner-Denver 3PDR9) 


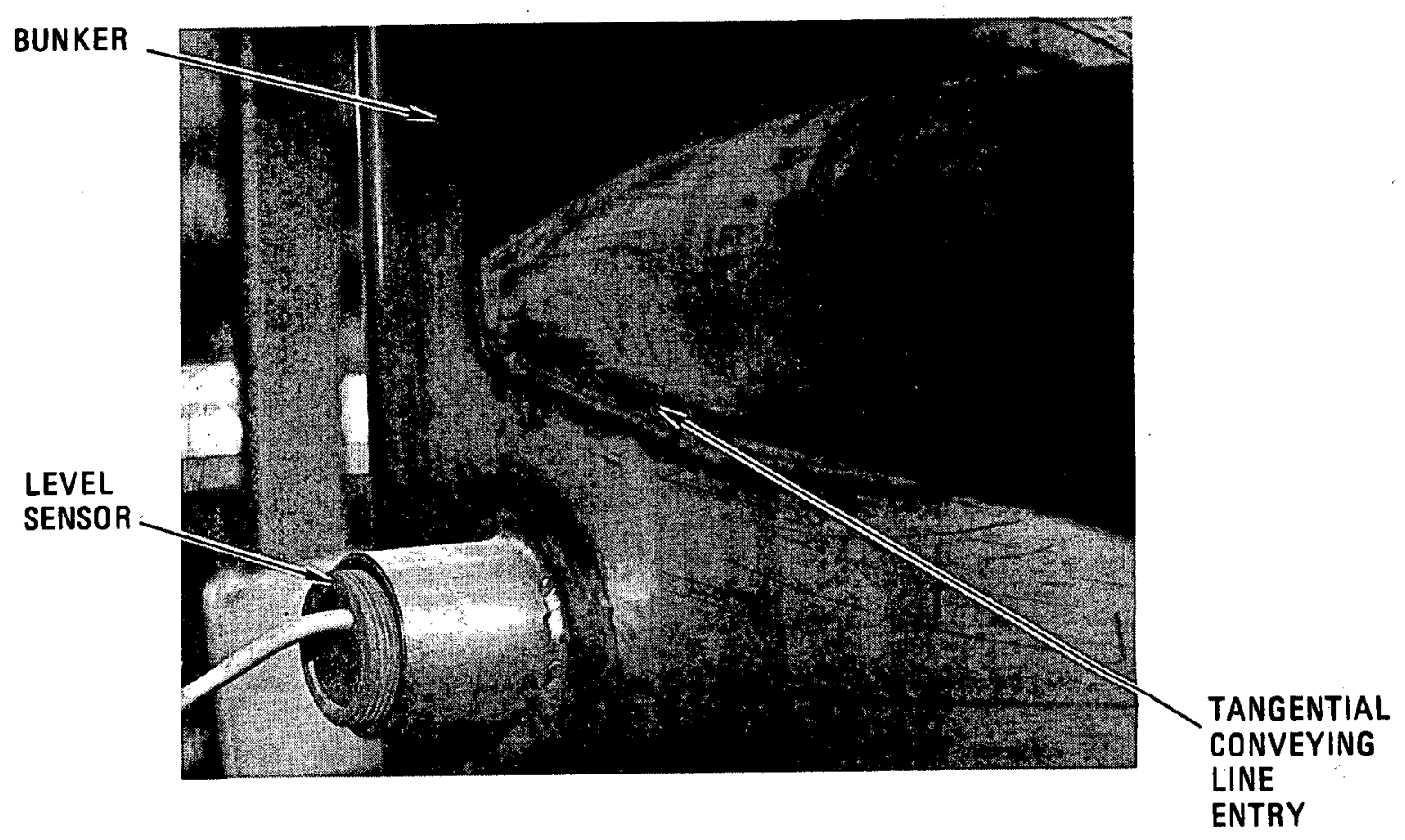

Fig. 15. Ultrasonic level sensor [5.08 cm (2 in.) diameter] used for indicating a maximum safe level in a storage bunker 
examination showed the faces of the sensors to be coated with a layer of very fine particles. When the'faces were cleaned, the alarm was deactivated. The general phenomenon of powder deposition on the sensors will be investigated, as will alternative level sensors.

\subsection{FEEDERS}

\subsubsection{Description}

A feeder is defined as a device which controls the rate at which material leaves a bunker or some other form of storage. The only mechanical feeders in the original system design are a star valve (Fig. 16), which meters crushed fuel elements to the primary burner, and a vibrating feeder (Fig. 17), which meters burned-back fuel particles to the classifier. The flow rate out of the other bunkers is controlled by the size of the outlet. It is important to verify that the flow rate is consistent with the capacity of the conveying system and that the orifice required for such a flow rate is not too small for steady flow. The bunker outlets are knifegate valves (Fig. 8).

\subsubsection{Feeding Through Orifices - General Comments}

Johanson (Ref. 3) derives a simple expression for the flow rate through an orifice using a force balance on an arch:

$$
F=\gamma \frac{\pi}{4} D^{2} \sqrt{\frac{D g}{4 \tan \theta}} \sqrt{\left(1-\frac{f f}{F F}\right)}=F_{i} \sqrt{\left(1-\frac{f f}{F F}\right)},
$$

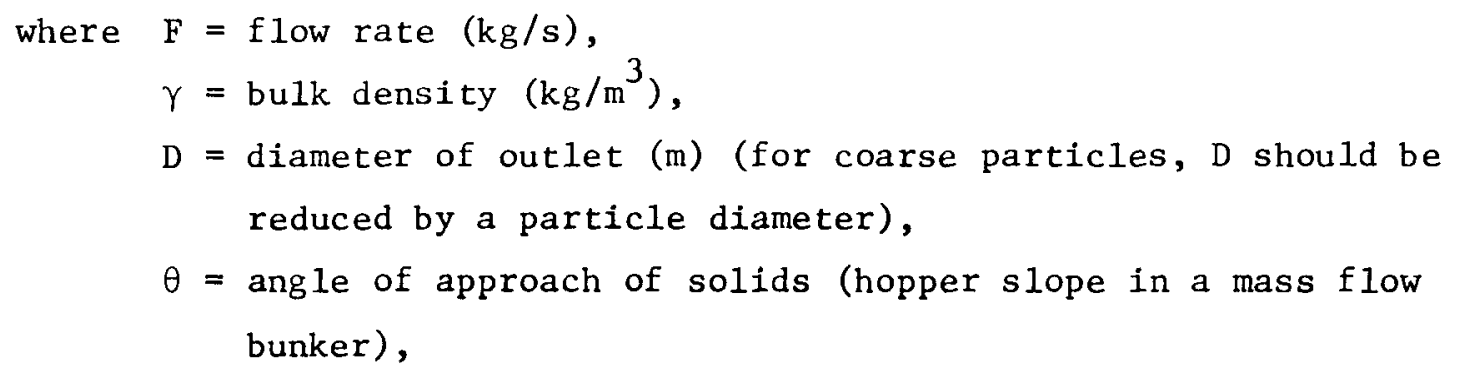


Fig. 16. Primary burner feeder 


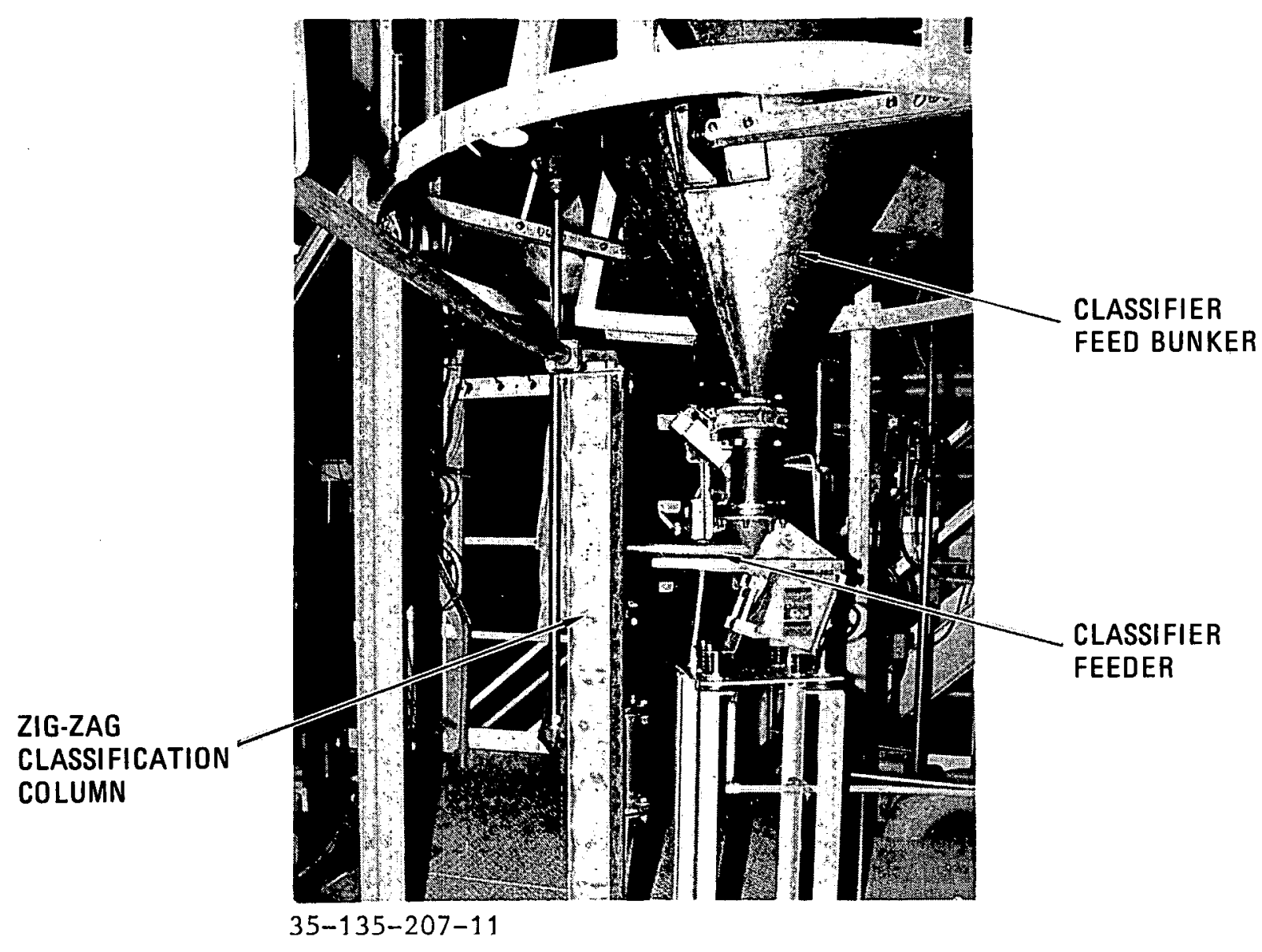

Fig. 17. Particle classifier feeder 


$$
\begin{aligned}
& \mathrm{ff}=\text { flow factor of the bunker, } \\
& F F=\text { flow function of the solid, } \\
& F_{i}=\text { flow rate of an ideal solid }(\mathrm{kg} / \mathrm{s}) .
\end{aligned}
$$

A simple extension of the force balance to include a pressure gradient due to flow of gas through the particulate solids yields

$$
F=F_{i} \sqrt{\left(1 \pm \frac{1}{\gamma g} \frac{d p}{d z}-\frac{f f}{F F}\right)},
$$

where $+(\mathrm{dp} / \mathrm{d} z)=$ pressure gradient in the same direction as the flow $(\mathrm{Pa} / \mathrm{m})$, $-(\mathrm{dp} / \mathrm{dz})=$ pressure gradient against the flow $(\mathrm{Pa} / \mathrm{m})$.

The last equation shows how a downflow of gas can be used to overcome the effect of cohesion and to increase the natural gravity flow rate. This latter effect is particularly marked when discharging from the burners. A negative pressure gradient can be created by upward leakage from a pneumatic conveying system which is at a higher pressure or from an upflow of gas needed to replace the volume vacated by solids flowing out of a bunker with a sealed top. Another phenomenon is an increase in the porosity in a flowing solid just above the bunker outlet. This results in an underpressure just above the outlet, the magnitude of which depends on the permeability of the material. The underpressure causes a negative pressure gradient, which tends to retard the flow, particularly of fine materials.

The minimum outlet size for a cohesive material can be estimated from flow property measurements using Jenike's flow model (Ref. 4). There is also a minimum outlet size for a free-flowing solid, based on a diameter needed to avoid mechanical interlocking. Normally, an outlet with a diameter nine times the average particle size is required.

A11 these factors need to be taken into consideration when a bunker must handle different solids which are to be conveyed pneumatically. The capacity of a conveying system is fixed by the maximum allowable pressure drop. The orifice size which gives the maximum conveyable flow rate for 
one material must be compatible with the minimum flow requirements of the other materials. If it is not, the orifice size must be changed, depending on which material is present.

\subsubsection{Testing}

4.7.3.1. Test Procedure. For bunkers with no feeding devices, the design requires that the flow rate be compatible with the capacity of the downstream conveying system. Since the secondary burner product bunker is presently at the end of the head-end, such considerations do not apply. The compatibility of the flow rate out of a bunker into the conveying line downstream from the bunker can only be completely verified during testing of that downstream system. Nevertheless, some indication is required during component testing. It is reasonable to assume that flow rates of less than $1 \mathrm{~kg} / \mathrm{s}(2.2 \mathrm{lb} / \mathrm{sec})$ can be transported by a conveying system with a maximum available pressure drop of $40 \mathrm{kPa}$ (12 in. $\mathrm{Hg}$ ), and this amount is the provisional acceptability criterion. If the minimum outlet should give too large a flow rate, design changes can be contemplated.

The primary burner feeder is to be calibrated in place over its entire range using the feed bunker load cells to measure change of weight.

The classifier feeder is to be calibrated using TRISO and BISO/TRISO fuel particle mixtures.

\subsubsection{Test Results. The test results for subsystems 1 through 6 are} as follows:

Subsystem No. 1 - Crusher Product Removal System. The maximum flow rate out of the screener in the Uniframe is approximately $0.36 \mathrm{~kg} / \mathrm{s}$ $(0.80 \mathrm{Ib} / \mathrm{sec})$, which can be handled comfortably by the conveying system. Crushed graphite was discharged from the crusher product bunker at $0.23 \mathrm{~kg} / \mathrm{s}(0.50 \mathrm{lb} / \mathrm{sec})$. 
Subsystem No. 2 - Primary Burner Feed System. The primary burner feed bunker load cells have been used to measure the capacity of the star valve at different speed settings for crushed graphite and for simulated fresh feed ( 83 wt \% graphite, 17 wt \% fertile TRISO "A" particles). The results are given in Fig. 18. Figure 19 shows the variation with time in the flow rate of simulated feed when beginning with a full bunker. The reason for this variation is most probably the tendency of fuel particles to percolate down through the crushed graphite, filling the interstices near the bunker outlet. As the bunker becomes empty, the flow rate of simulated fresh feed tends to approach that of crushed graphite.

Subsystem No. 3 - Primary Burner Product Removal System. The feed rate of product to the removal system from the burner can be controlled by using orifices of different sizes; however, such a technique requires not only good predictions but also repeated assembly and disassembly of the burner outlet. To alleviate these problems, a variable width knifegate valve (Fig. 20) was installed. The degree to which the knifegate valve opens can be controlled from the control room. It has proved to be most satisfactory for dumping product varying from cold crushed graphite to hot $\left(700^{\circ} \mathrm{C}\right)$ burned-back fuel particles at rates which can be handled by the conveying system.

Crushed graphite has been discharged from the primary burner product bunker through a $0.05-\mathrm{m}$ orifice at $0.23 \mathrm{~kg} / \mathrm{s}$. The bunker must be able to discharge crushed graphite in the event of an aborted primary burner run. Simulated feed, containing 17 wt \% TRISO fuel particles, discharged through a $0.05-m$ orifice so fast that the conveying line plugged and caused the blower relief valve to be actuated. Clearly, fuel particles percolated to the bottom of the bunker causing a high initial feed rate. At diameters less than $0.05 \mathrm{~m}$, however, crushed graphite is known to bridge. Similar difficulties could be expected with the crusher product bunker. 


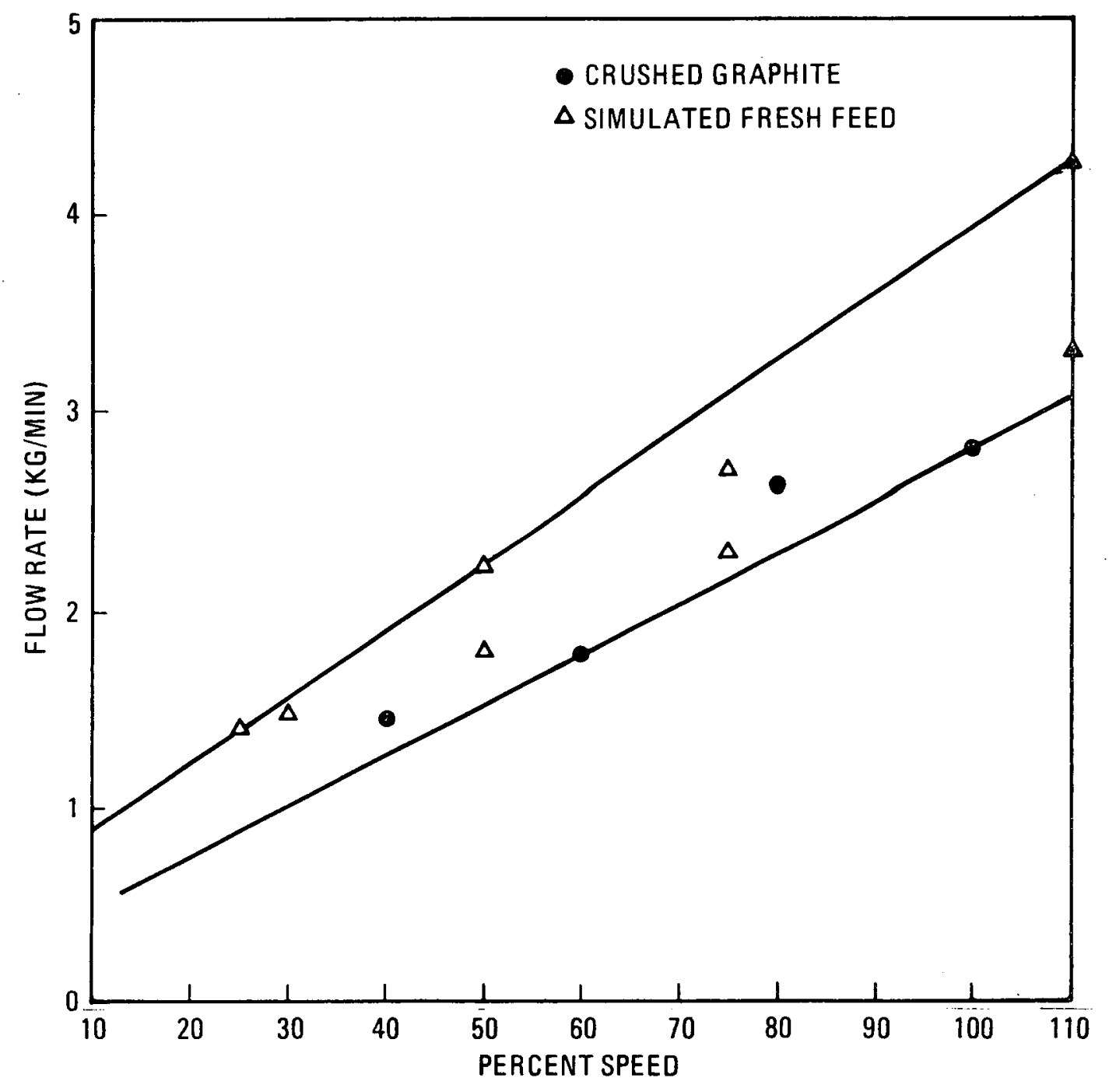

Fig. 18. Flow rate into primary burner versus star valve speed setting 


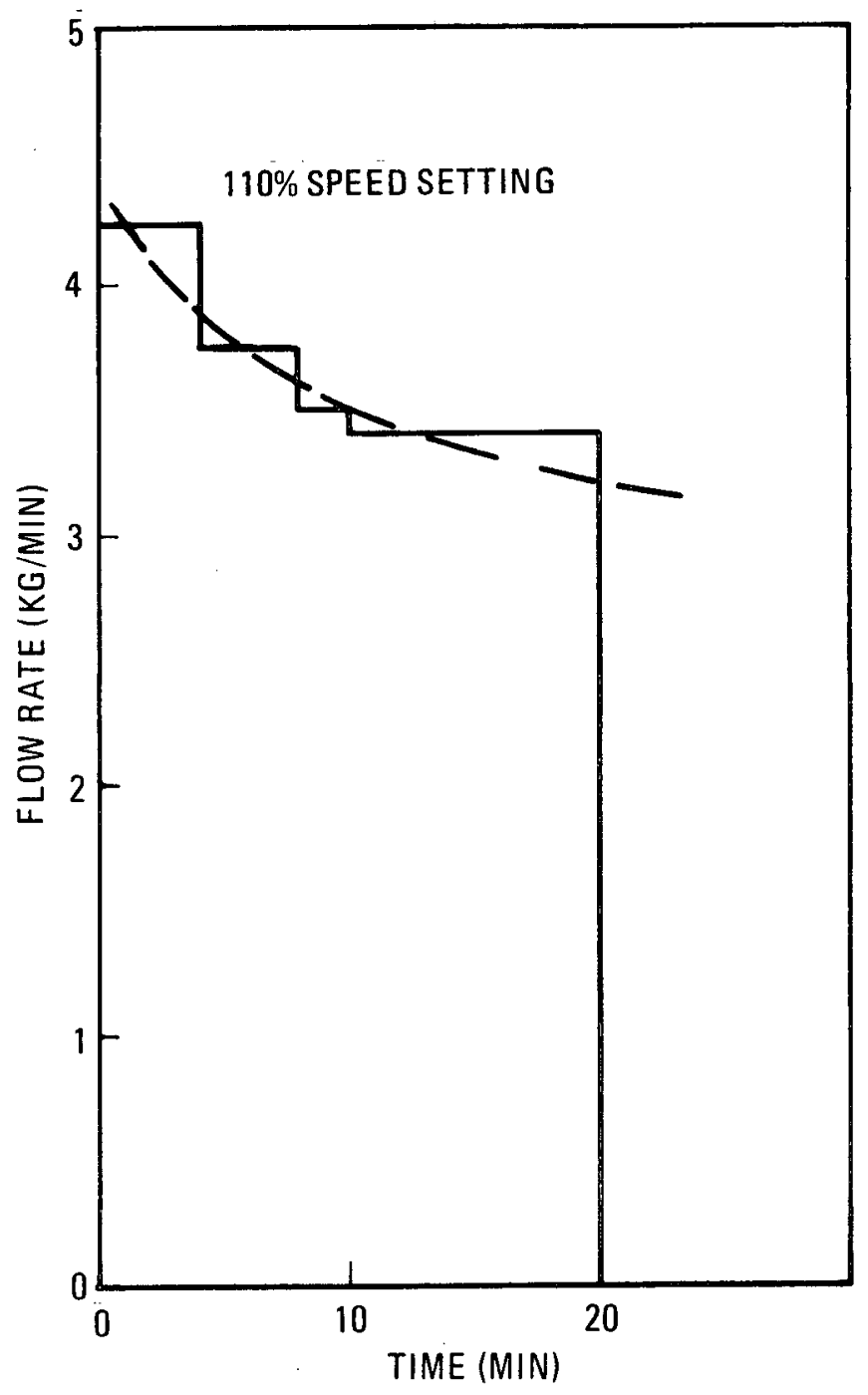

Fig. 19. Variation of flow rate of simulated fresh feed with time 


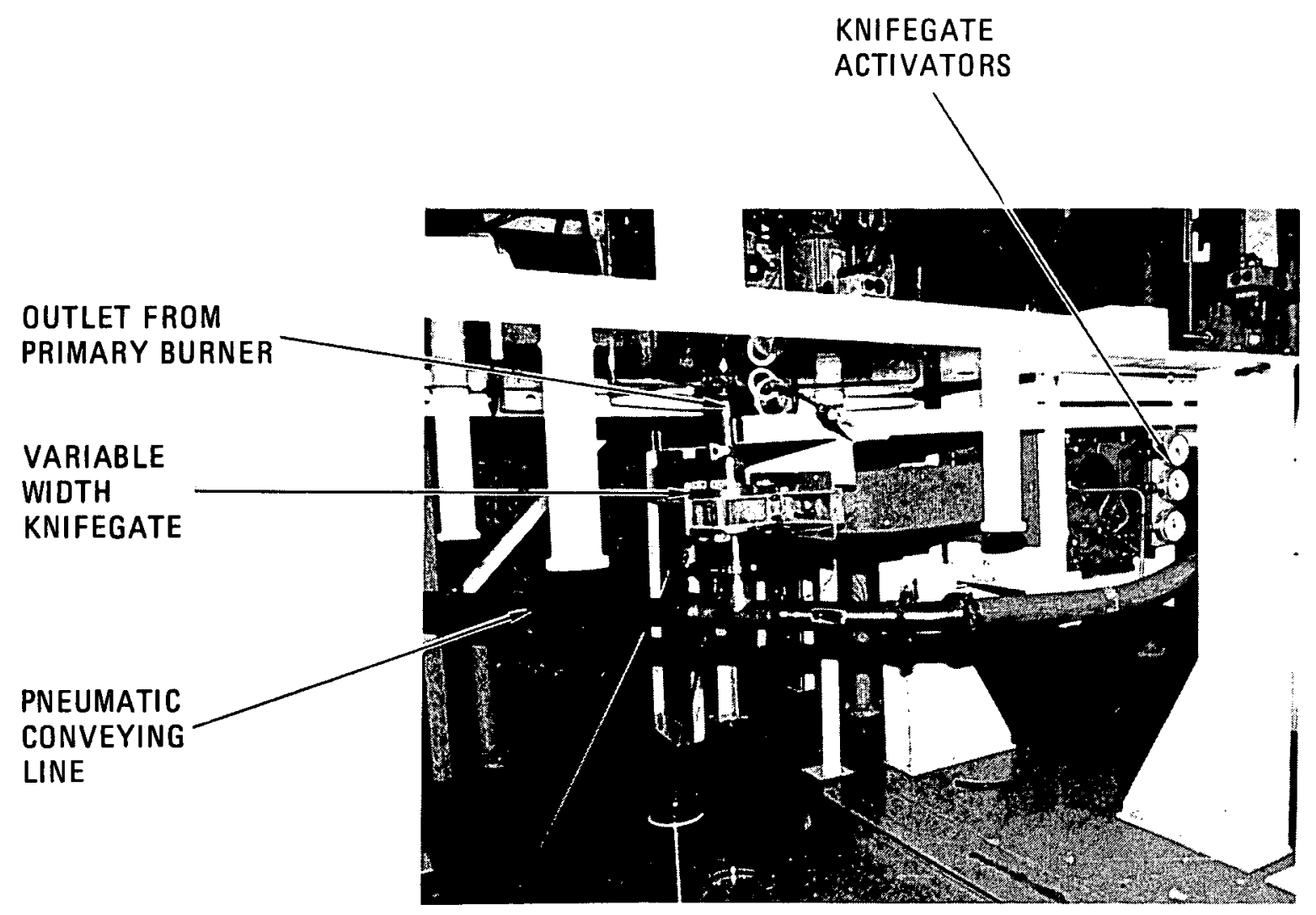

$35-135-207-23$

Fig. 20. Variable width knifegate in position under the primary burner 
TRISO fuel particles were discharged through a $0.025-\mathrm{m}$ orifice at $0.36 \mathrm{~kg} / \mathrm{s}$, whereas BISO fuel particles are estimated to have a discharge rate of up to $1.0 \mathrm{~kg} / \mathrm{s}$ through the same $0.025-\mathrm{m}$ orifice. TRISO fuel particles did not discharge through a $0.019-\mathrm{m}$ orifice due to a bridge of fines. Segregation may occur with burned-back BISO/TRISO fuel mixtures, in which case the flow rate through a $0.025-\mathrm{m}$ orifice $(1.0 \mathrm{~kg} / \mathrm{s}$ for BISO alone) may prove too high for the available system pressure drop. A rotary feeder valve, similar to that used beneath the primary burner feed bunker, was placed beneath the primary burner product hopper to throttle the discharge of fuel particles should segregation cause system overloading (see Section 4.7.5, Improvements).

Subsystem No. 4-Particle Classifier Feed System. The results for TRISO/BISO mixtures are given in Table 5. The results for TRISO/ TRISO fue1 particles are given in Fig. 21.

Subsystem No. 5 - Particle Crusher Feed System. The classifier fissile product bunker needs to feed material for transport to the particle crusher feed bunker or for recycle to the classifier feed bunker for reclassification. Since different feed rates are required, a small star valve was installed (see Section 4.7.5, Improvements). The feed rate out of the particle crusher feed bunker is controlled by the speed of the particle crusher.

Subsystem No. 6 - Secondary Burner Product Removal System. The secondary burner outlet feed rate is controlled by intermittent actuation of the secondary burner outlet valve. A continuously open outlet valve was found to provide too great a feed rate for the system to handle. The flow rate out of the secondary burner product bunker is not relevant.

Subsystem No. 6 also contains the removal of BISO particles from the classifier fertile product bunker. In order to provide the flexibility to feed and recycle both BISO and FSV fertile TRISO particles, a sma11 star valve was installed (see Section 4.7.5, Improvements). 
TABLE 5

PARTICLE CLASSIFIER FEEDER CAPACITIES WITH BISO/TRISO

FUEL PARTICLES ( $100 \%$ VIBRATION)

\begin{tabular}{l|l}
\hline $\begin{array}{c}\text { Composition of } \\
\text { Mixture }\end{array}$ & \multicolumn{1}{c}{$\begin{array}{c}\text { Feed Rate } \\
(\mathrm{kg} / \mathrm{min})\end{array}$} \\
\hline $37 \%$ BISO 63\% TRISO & $\begin{array}{l}0.850 \\
78 \% \text { BISO 22\% TRISO }\end{array}$ \\
$\begin{array}{l}1.70 \text { initially (excess } \\
\text { BISO) decreasing to 1.00 } \\
\text { (excess TRISO). } \\
1.80\end{array}$ \\
\hline
\end{tabular}

NOTE: The factor 4 difference in density with BISO and TRISO particles is enough to cause significant segregation, even in operations such as filling and emptying a bunker. 


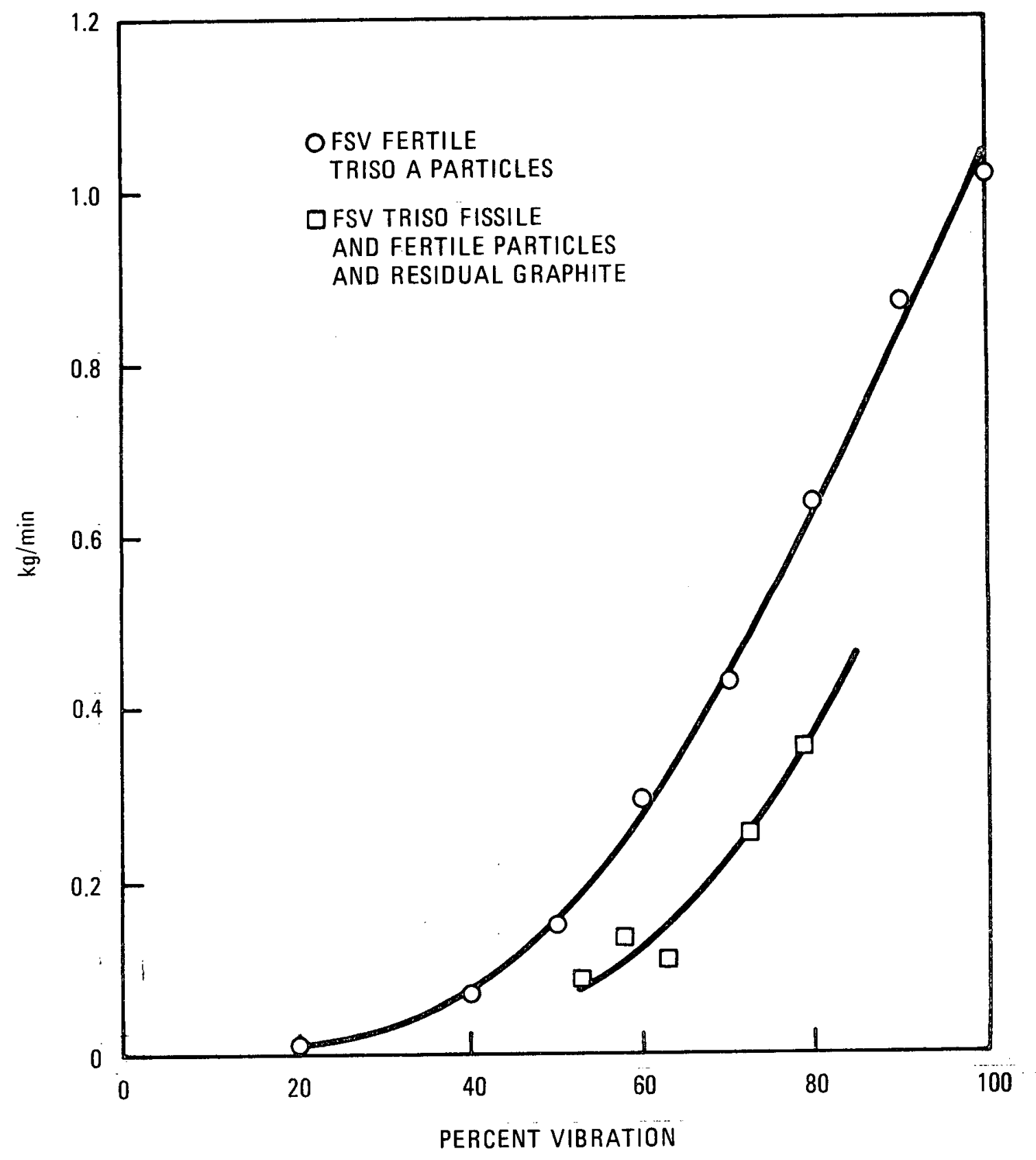

Fig. 21. Particle classifier vibrating feeder calibration curves 


\subsubsection{Acceptability}

The primary burner feeder provides satisfactory performance except for feed rate accuracy. The feed rate accuracy criteria of $\pm 5 \%$ is considered to be an impractical goal for a rotary feeder valve using nonhomogenous feed. The feeder performance is acceptable for primary burner operations and, hence, no design alterations are currently being considered.

The classifier feeder acceptance requirement of $1500 \mathrm{~g} / \mathrm{min}$ was attained with the simulated feed material of $78 \%$ BISO/22\% TRISO fuel particles; however, segregation of the fuel particle types caused the feed rate to fall below the $1500 \mathrm{~g} / \mathrm{min}$ value near the end of the run when virtually all the remaining feed was TRISO.

To eliminate the need to change bunker outlet orifices each time a different feed material is deposited in a bunker, rotary feeders, or star valves, were installed under the following: crusher product bunker, primary burner product bunker, fertile classifier product bunker, and fissile classifier product bunker (see Section 4.7.5, Improvements).

The feed rates out of both the primary and secondary burners are acceptable.

\subsubsection{Improvements}

Steel shot, glass beads, and crushed graphite were used as feed materials for the tests to simulate actual feed materials encountered in pilot plant operations without the radiological safety constraints that would have been required if actual feed materials had been used. By comparing the particle size and density of the steel and glass with that of fuel particles, rotary valve performance can be extrapolated to predict valve performance with fuel particles. By varying valve clearances and valve speeds during the tests, the proper valve settings were determined. System testing during sequential pilot plant tests will verify the valve performance under actual operating conditions. Results of these tests are 
shown in Fig. 22 for a 0.05-m inlet valve and in Fig. 23 for a 0.10-m inlet valve. The smaller valves, which are the same as the primary burner feed valve shown in Fig. 16, have been installed under the classifier product bunkers with a 4.76-mm clearance. The larger valves have been installed under the crusher product and primary burner product bunkers; the latter installation is shown in Fig. 24.

Final verification of flow rates will be obtained during plant sequential operation.

\subsection{WEIGH CELLS}

\subsubsection{Description}

The bunkers rest on load cells (Fig. 25) which continuously record the material weight. Upon command, a value of the weight, averaged over 10 seconds, is printed out. Several special provisions have been made to ensure that accurate readings are obtained. The bunker assemblies themselves are supported on three load cells, which are mounted on a cage (Fig. 26). Al1 connecting lines either contain metal bellows or, if flexible, are unsupported over at least 0.6 horizontal meter ( 2 horizontal feet). In order to prevent rotation of the bunkers, tie bars are attached to the bunker and the support cage (Fig. 27).

The system consists of three subsystems ( $A, B$, and $C$ ), each having the capacity for four bunkers of three load cells each. The following schematic illustrates the present bunker/weigh cell layout:

Cell 1 - primary burner system

Subsystem A- Ce11 2 - primary burner system

Cell 3 - primary burner feed bunker

Cell 4 - crusher product bunker 


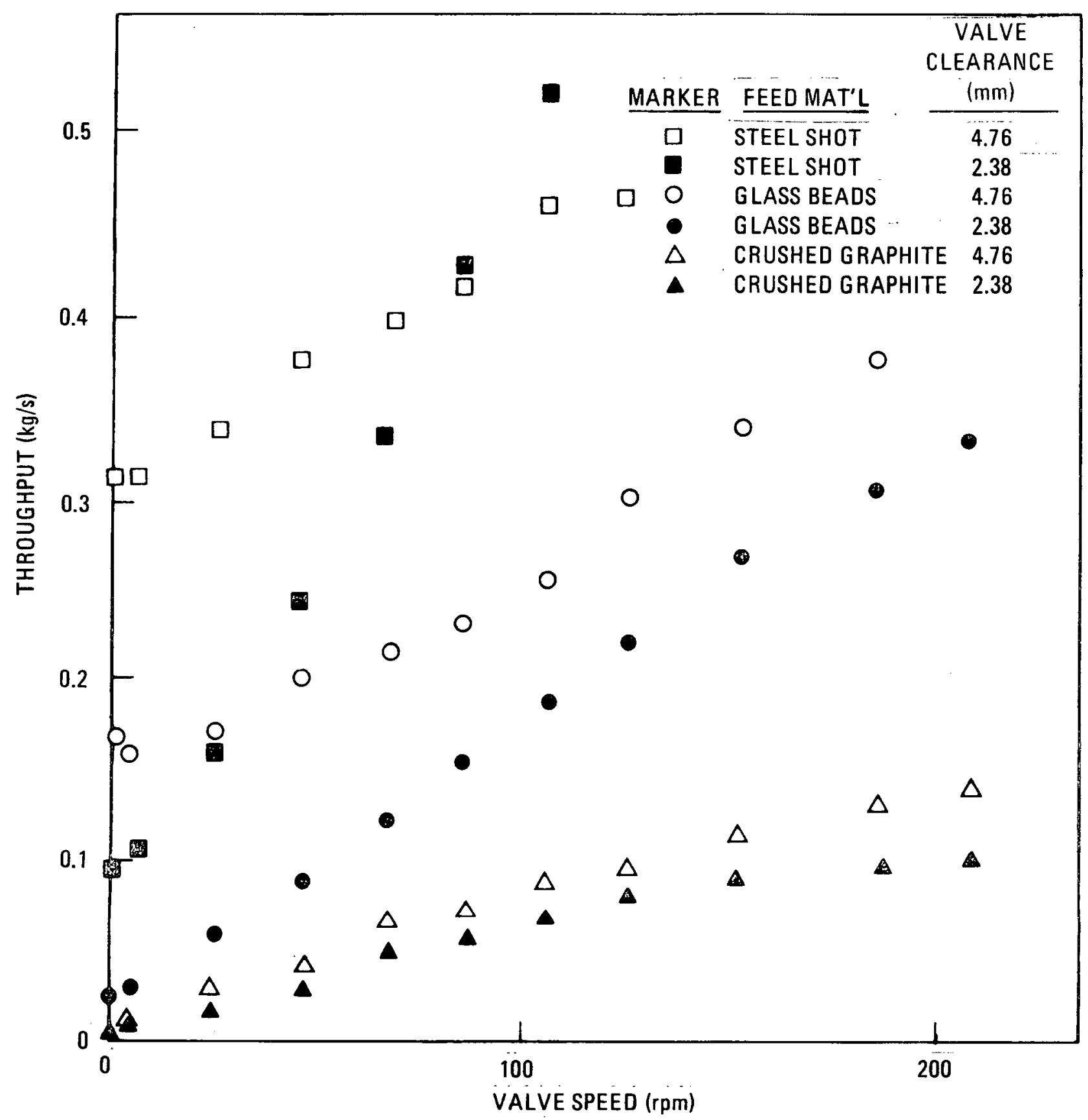

Fig. 22. Rotary feeder valve test results $[0.05 \mathrm{~m}$ (2 in.) inlet] 


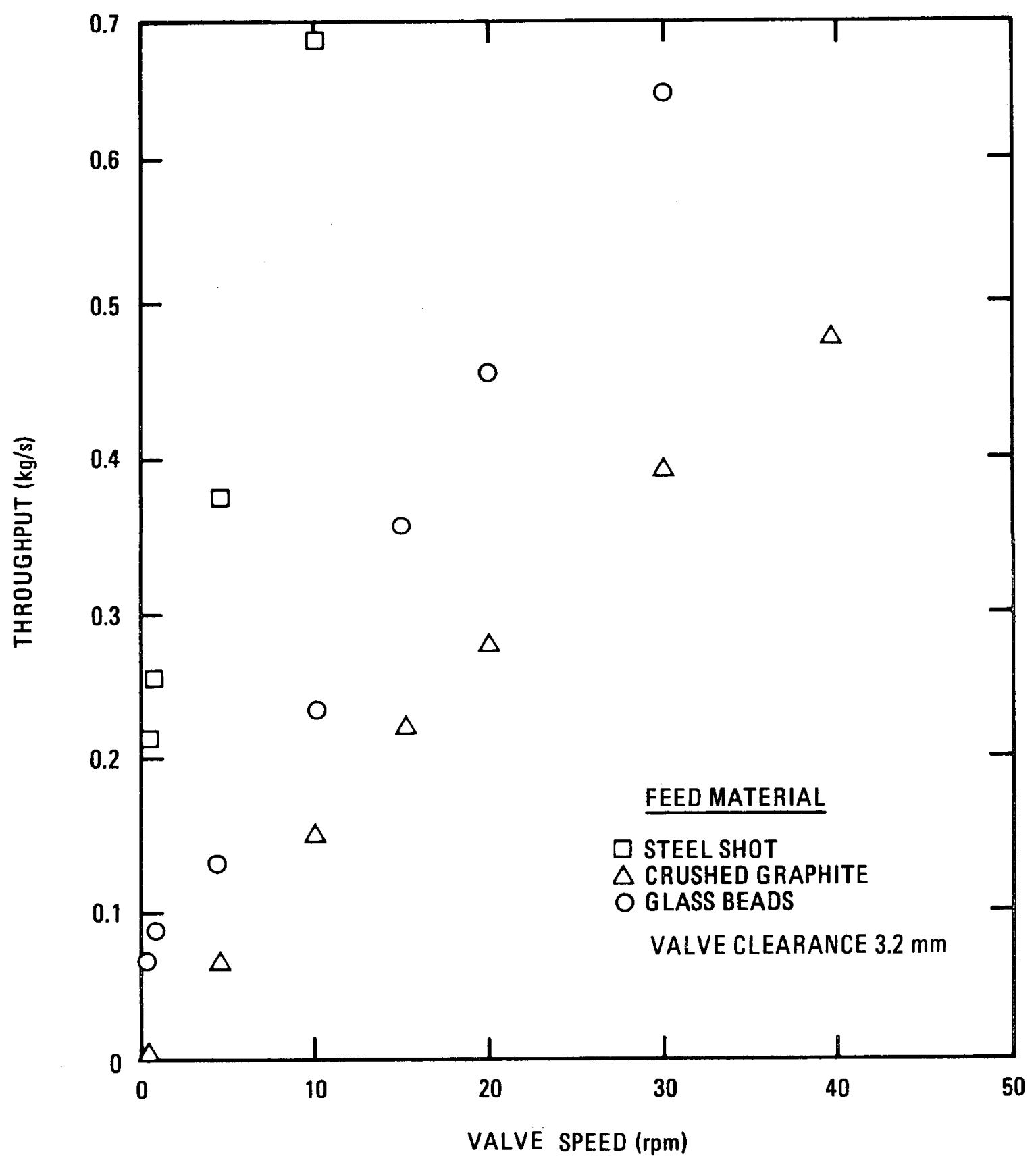

Fig. 23. Rotary feeder valve test results $[0.010 \mathrm{~m}$ (4 in.) inlet] 


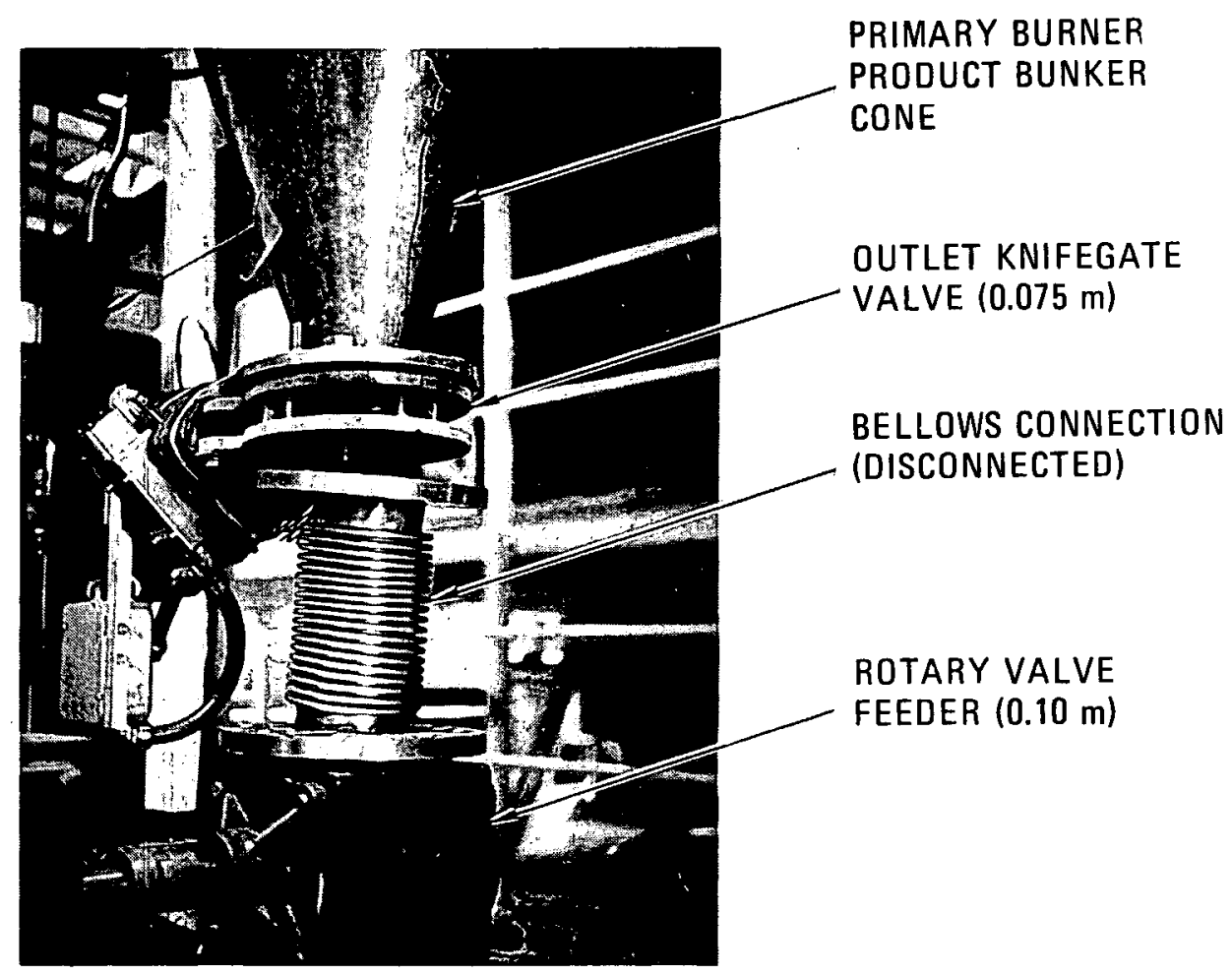

Fig. 24. Rotary feeder installed under the primary burner product bunker 



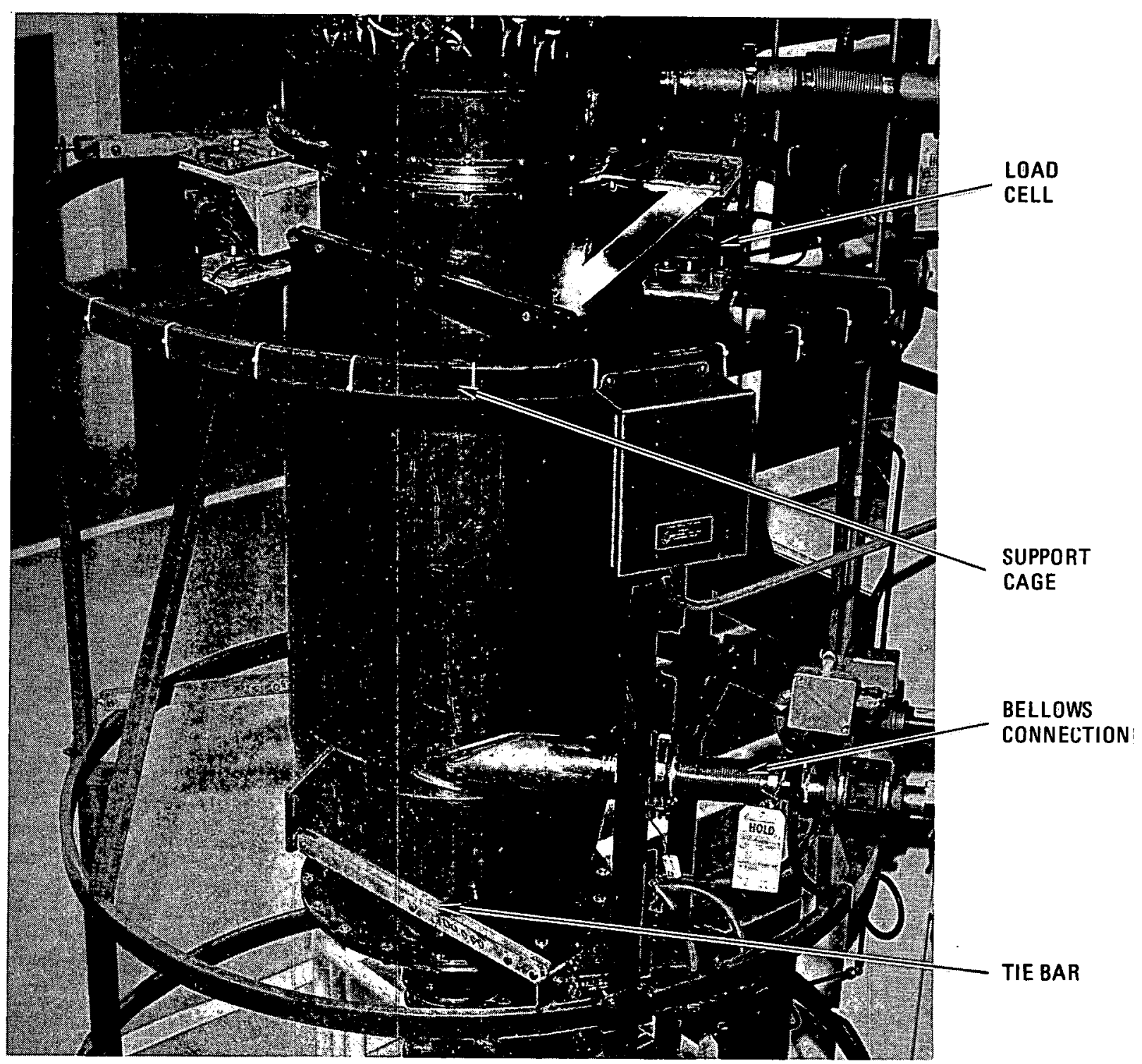

Fig. 26. Bunker and support cage $[63.50 \mathrm{~cm}$ (25 in.) diameter bunker ] 


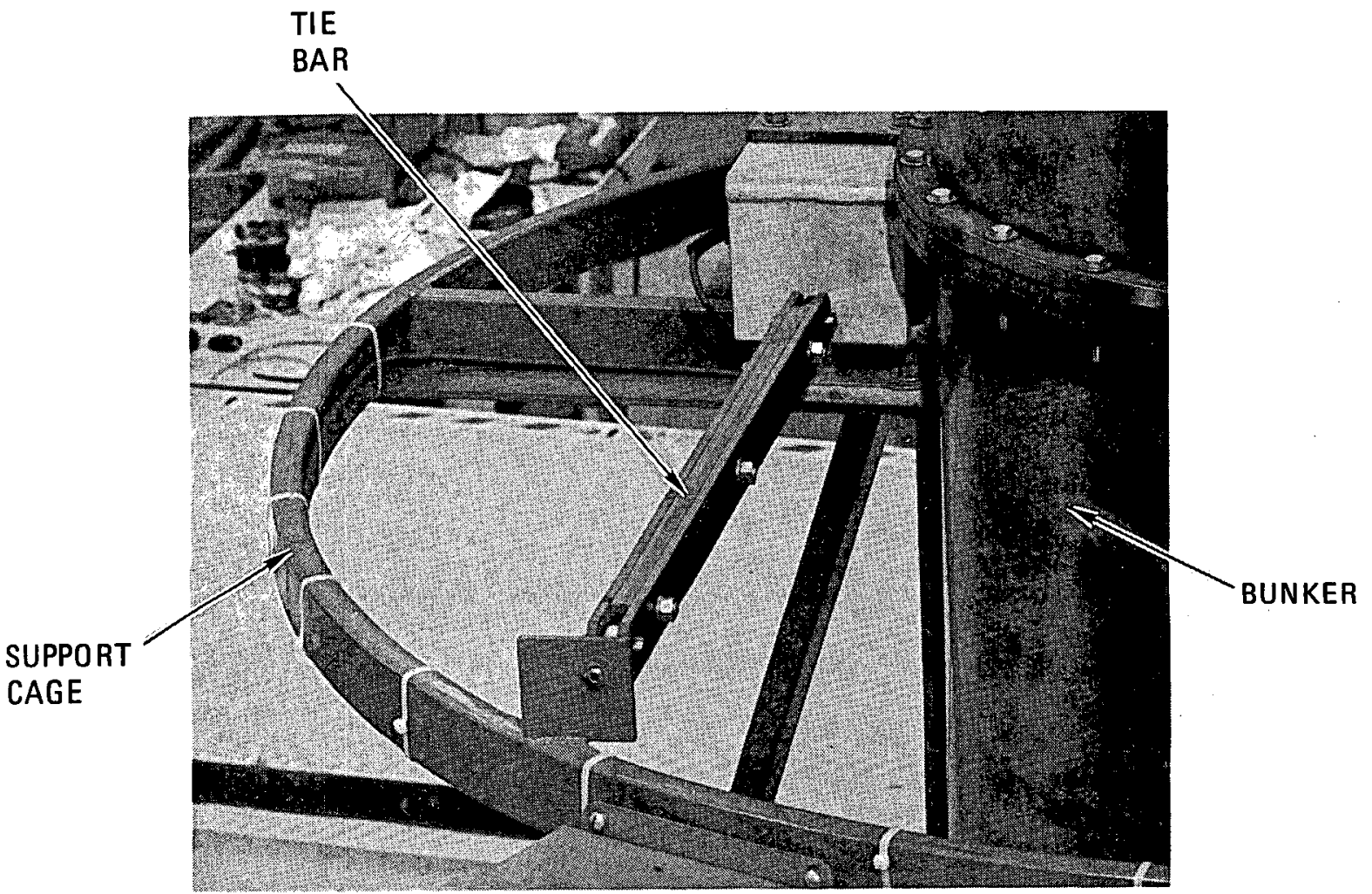

Fig. 27. Bunker tie bar used to prevent rotation of the bunker on its load cells 
Cell 1 - classifier system

Subsys tem $B$

Cel1 2 - classifier system

Cell 3 - classifier feed bunker

Cel1 4 - primary burner product bunker

Cell 1 - particle crusher feed bunker

Subsystem $\mathrm{C}-$ Cell 2 - secondary burner product bunker

Cell 3 - Not in use

Ce11 4 - Not in use

One-half of the entire weigh system is utilized for monitoring the solids handling bunkers; the other half is utilized for various other pilot plant systems.

\subsubsection{Testing}

4.8.2.1. Test Procedure. The maximum design basis weight was placed on each bunker individually for load cell calibration (except the crusher product bunker which has a design basis capacity beyond the presently available calibration weight total of $386 \mathrm{~kg}$ ). The design basis weights, as shown in Table 6, were placed on and removed from each bunker several times in order to adjust the electronic weigh systems for accuracy and repeatability.

\subsubsection{Test Results. The system is very sensitive, having sufficlent} resolution to detect and display a change in load of $10 \mathrm{~g}$. Therefore, any load equal to or greater than $10 \mathrm{~g}$ transmitted to the load cell either through the bunker or the structure will be seen as a change in output on the display. In other words, not only are the external connections to the bunker very important, but the external connections to the support structure are just as important. For example, the particle crusher and the particle crusher feed bunker are supported by common structure. When the particle crusher is running, vibration from it is transmitted through the common support structure to the load cell pad causing a $\pm 1 \mathrm{~kg}$ fluctuation in the particle crusher feed bunker weight display. 
TABLE 6

BUNKER DESIGN BASIS WEIGHT CAPACITIES

\begin{tabular}{l|c}
\hline \multicolumn{1}{c|}{ Bunker } & $\begin{array}{c}\text { Maximum Design Load } \\
(\mathrm{kg})\end{array}$ \\
\hline Crushed product bunker & $545.5^{(\mathrm{a})}$ \\
Primary burner feed & 106.8 \\
Primary burner product & 272.7 \\
Classifier feed & 215.9 \\
Particle crusher feed & 63.6 \\
Secondary burner product & 63.7 \\
\hline
\end{tabular}

(a) $386 \mathrm{~kg}$ maximum available calibration weight. 
Any blowback systems, blowers, and burner systems related to a bunker must be turned off prior to taking weight readings. People must be cleared from the vicinity of the bunker platform and nearby elevated walkways for maximum accuracy. In general, no differential pressures are allowed across bunkers to maintain calibration accuracies. Turning on a blower, for instance, gives a change in the readout of approximately $5 \mathrm{~kg}$. The movement of a person on the platform can cause a change of approximately $2 \mathrm{~kg}$.

The accuracies obtained for the individual weigh cell systems are given in Table 7.

\subsubsection{Acceptability}

The results obtained satisfy the design criteria, with the proviso that all the precautions discussed are taken. Support structures are being stiffened to increase the pilot plant load cell accuracies. 
TABLE 7

ACCURACIES OF WEIGH CELL SYSTEMS

\begin{tabular}{l|l|l}
\hline \multicolumn{1}{c|}{ Subsystem } & Accuracy & Repeatability \\
\hline No. 1 - crusher product bunker & $< \pm 0.5 \%$ of avilable load & $< \pm 0.1 \%$ of available load \\
No. 2 - primary burner feed bunker & $< \pm 0.5 \%$ of design load & $< \pm 0.1 \%$ of design load \\
No. 3 - primary burner product bunker & $< \pm 0.5 \%$ of design 1oad & $< \pm 0.1 \%$ of design load \\
No. 4 - classifier feed bunker & $< \pm 0.5 \%$ of design $10 a d$ & $< \pm 0.1 \%$ of design load \\
No. 5 - particle crusher feed bunker & $< \pm 0.5 \%$ of design 1oad & $< \pm 0.1 \%$ of design load \\
No. 6 - secondary burner product bunker & $< \pm 0.5 \%$ of design load & $< \pm 0.1 \%$ of design load \\
\hline
\end{tabular}




\section{ACKNOWLEDGMENTS}

The authors would like to express our appreciation to the following: J. W. Allen and R. D. Zimmerman for their manageria1 guidance, R. W. Wheatly and W. W. Johnston for their efforts in assembly and testing of the system, and R. D. Crabtree for his valuable assistance with the weigh cell system and other electrical components. 


\section{REFERENCES}

1. Heath, C. A., and M. E. Spaeth, "Reprocessing Development for HTGR Fuels," General Atomic Report GA-A13279, February 15, 1975.

2. delesdernier, D. L., "Pneumatic Classification of Fort St. Vrain Fuel Particles," ERDA Report GA-A13135, General Atomic Company, June 30, 1975.

3. Johanson, J. R., "Method of Calculating Rate of Discharge from Hoppers and Bins," Trans. Soc. Mining Eng., 69 (March 1965).

4. Jenike, A. W., "Storage and Flow of Solids," Utah Engineering Experiment Station, University of Utah, Bulletin 123, 1964. 